Bentham OPEN
CrossMark
Content list available at: www.benthamopen.com/TOBIOTJ/
DOI: $10.2174 / 1874070701812010056$

REVIEW ARTICLE

\title{
Microbial Diversity of Mer Operon Genes and Their Potential Rules in Mercury Bioremediation and Resistance
}

\author{
Martha M. Naguib ${ }^{1}$, Ahmed O. El-Gendy ${ }^{2}$ and Ahmed S. Khairalla,** \\ ${ }^{I}$ Department of Biotechnology and Life Sciences, Faculty of Post Graduate Studies for Advanced Sciences, Beni-Suef \\ University, Beni-Suef 62511, Egypt \\ ${ }^{2}$ Department of Microbiology and Immunology, Faculty of Pharmacy, Beni-Suef University, Beni-Suef 62511, Egypt
}

Received: October 27, 2017

Revised: February 23, 2018

Accepted: March 16, 2018

\begin{abstract}
:
Background:

Mercury is a toxic metal that is present in small amounts in the environment, but its level is rising steadily, due to different human activities, such as industrialization. It can reach humans through the food chain, amalgam fillings, and other sources, causing different neurological disorders, memory loss, vision impairment, and may even lead to death; making its detoxification an urgent task.
\end{abstract}

\begin{abstract}
Methods:
Various physical and chemical mercury remediation techniques are available, which generally aim at: (i) reducing its mobility or solubility; (ii) causing its vaporization or condensation; (iii) its separation from contaminated soils. Biological remediation techniques, commonly known as bioremediation, are also another possible alternative, which is considered as cheaper than the conventional means and can be accomplished using either (i) organisms harboring the mer operon genes (mer $B, \operatorname{mer} A, \operatorname{mer} R$, merP, merT, merD, $\operatorname{merF}, \operatorname{mer} C$, merE, merH and $\operatorname{mer} G$ ), or (ii) plants expressing metal-binding proteins. Recently, different $m e r$ determinants have been genetically engineered into several organisms, including bacteria and plants, to aid in detoxification of both ionic and organic forms of mercury.
\end{abstract}

\section{Results:}

Bacteria that are resistant to mercury compounds have at least a mercuric reductase enzyme (MerA) that reduces $\mathrm{Hg}^{+2}$ to volatile $\mathrm{Hg}$, a membrane-bound protein (MerT) for $\mathrm{Hg}^{+2}$ uptake and an additional enzyme, MerB, that degrades organomercurials by protonolysis. Presence of both merA and merB genes confer broad-spectrum mercury resistance. However, mer A alone confers narrow spectrum inorganic mercury resistance.

\section{Conclusion:}

To conclude, this review discusses the importance of mercury-resistance genes in mercury bioremediation. Functional analysis of mer operon genes and the recent advances in genetic engineering techniques could provide the most environmental friendly, safe, effective and fantastic solution to overcome mercuric toxicity.

Keywords: Mercury, Mercury toxicity, Biogeochemical cycle, Mercury remediation, Resistance mechanisms, Mer operon.

\section{INTRODUCTION}

For a long time, the term "heavy metals" had been widely used for metals associated with contamination and eco

\footnotetext{
"Address correspondence to this author at the Department of Microbiology and immunology, Faculty of Pharmacy, Beni-Suef University, Beni-Suef 62511, Egypt, Tel: +2-012-234-76015; E-mails: ahmed.elgendy@pharm.bsu.edu.eg, ahmedkhairalla@pharm.bsu.edu.eg
} 
-toxicity. The International Union of Pure and Applied Chemistry (IUPAC) recommended using the term "toxic metal" as an alternative to "heavy metal" [1]. Toxic metals are stable and persistent environmental contaminants [2]. Many metals such as mercury, cadmium, chromium, zinc, lead, copper, arsenic etc., used in different industries, are releasing its toxic ions and introducing it into the ecosystem leading to toxic effects, affecting humans, animals, plants, and microbial communities [3]. Also, some toxic metals naturally exist in very low concentrations in the ecosystem and are required in trace amounts as nutrients by microbial communities but in relatively higher concentration, they form toxic complexes on the biological cell $[3,4]$.

Mercury is the 16th rarest element on the earth [5] and considered as one of the mobile and toxic metals that exist naturally in low concentrations in the environment, and can be changed between different forms. It is the only metal to be liquid at room temperature. It can also exist as gas due to its high vapor pressure [6 - 8].

It is a major environmental pollutant especially methylmercury ( $\mathrm{MeHg}$ ) form in the aquatic regions. It can accumulate in biota so can reach and affect both wildlife and human seriously. It is one of the environmentally stable and persistent toxins for long periods, also it can be accumulated in different biological tissues [9, 10].

This review aims to cover all aspects related to the environmental biogeochemical cycle of mercury, the roles of mer genes in microbial adaptation to mercury, and potential bacterial remediation strategies of this toxic metal.

\section{MERCURY BIOGEOCHEMICAL CYCLE}

Environmental mercury cycle, as illustrated in Fig. (1), is usually facilitated biotically and abiotically between soils, water and atmosphere [11]. Mercury exists in the atmosphere in gaseous, particulates, and aqueous soluble forms [12] but gaseous form represents about $95 \%$ of atmospheric mercury [13] and it remains in the atmosphere for long periods. So, it can reach the far distance that should be considered as a huge environmental concern $[12,14,15]$.

\subsection{Oxidation Processes}

In the atmosphere, $\mathrm{Hg}$ abiotically oxidized to $\mathrm{Hg}^{+2}$ through photo-oxidation reactions, mediated by $\mathrm{O}_{2}$ through its interaction with hydrogen peroxide, ozone, sulfhydryl compounds, free radicals as $\mathrm{Br}$, and by $\mathrm{UV}-\mathrm{B}$ in presence of $\mathrm{Cl}_{2}$ and photoreactive compounds as benzoquinone in presence of water droplets $[11,12,16]$.

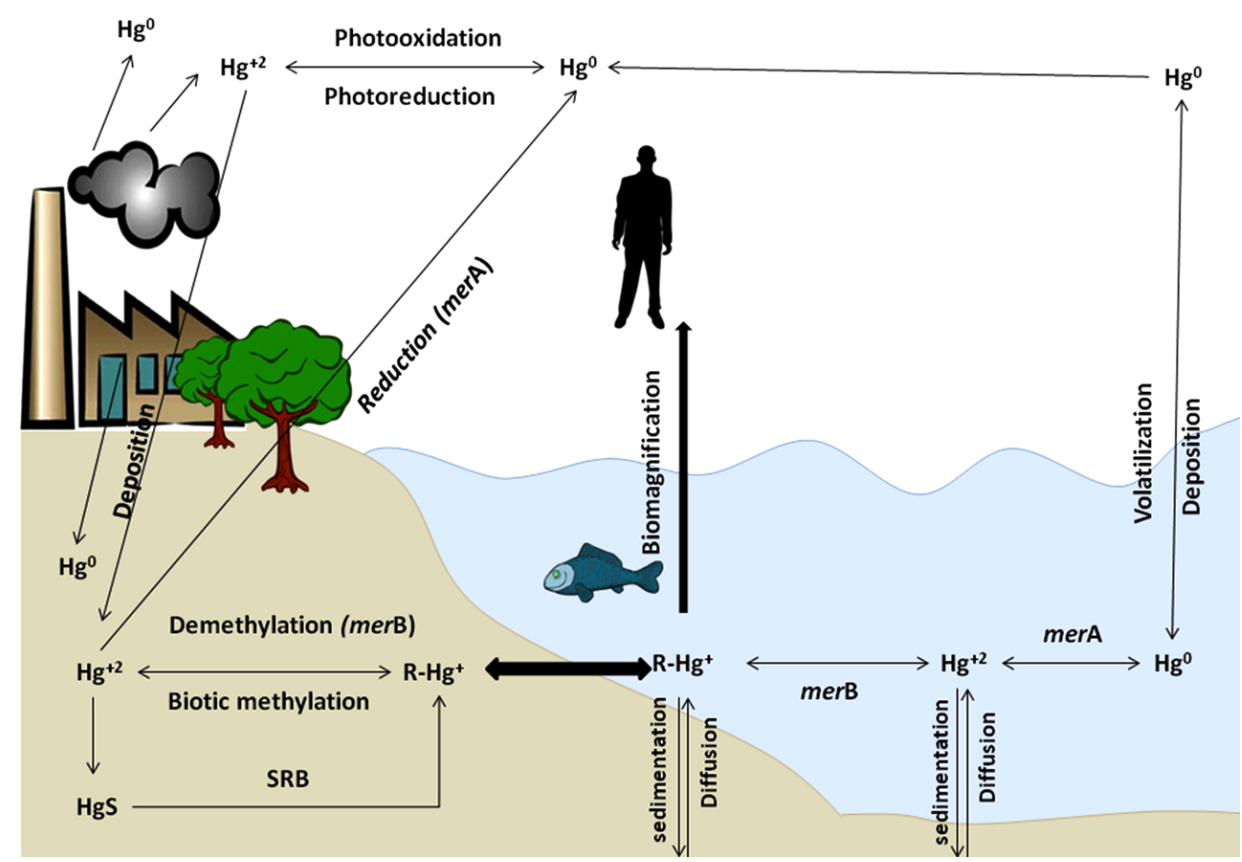

Fig. (1). Environmental mercury biogeochemical cycle [10].

Biotic $\mathrm{Hg}$ oxidation (bio-oxidation) in aerobic and phototrophic microorganisms is catalyzed by hydroperoxidases, kat $\mathrm{G}$ and kat $\mathrm{E}$ [13] or other oxidases [17]. Algae, plants and animals catalase and peroxidases are also capable of oxidizing $\mathrm{Hg}[17$ - 19].

Anaerobic $\mathrm{Hg}$ oxidation mechanism by Desulfovibrio desulfuricans ND132 bacteria is unknown as obligate 
anaerobes do not carry such catalase or peroxidase genes but Colombo, Ha et al. 2013 suggested an alternative oxidation pathway influenced by reactive functional thiol groups of different anaerobic bacteria [17, 19] consistent with previous studies in which thiol moiety of organic compounds such as glutathione [20] and reduced humic acid [21] can bind and oxidize $\mathrm{Hg}$.

\subsection{Reduction Processes}

Biotic $\mathrm{Hg}^{+2}$ reduction to $\mathrm{Hg}$ occurs by bacterial mercuric reductase enzyme encoded by merA gene on mer operon (described later) [8, 11, 22], anaerobic Geobacter sulfurreducens PCA, Geothrix fermentans H5, Cupriavidus metallidurans AE104, Shenwella oneidensis MR-1 and Geobacter metallireducens GS-15 was found to reduce $\mathrm{Hg}^{+2}$ to $\mathrm{Hg}$ independent on the mer system but its need an electron acceptors and electron donors to suggest activity of respiratory electron transport chains. Its activity is effective at too low $\mathrm{Hg}^{+2}$ concentrations compared to amounts required for mer operon induction. Anaerobic bacteria showed dual role in the $\mathrm{Hg}$ redox cycle by both oxidizing $\mathrm{Hg}$ and reducing $\mathrm{Hg}^{+2}$ by unidentified reduction system other than mer system [19, 22].

The abiotic $\mathrm{Hg}^{+2}$ reduction is done not only by photochemical reactions but also via dark reactions [23] using organic matter free radicals as fulvic [24] and humic acid-associated free radicals [18].

\subsection{Methylation Process}

Biotic $\mathrm{Hg}^{+2}$ methylation is a natural bacterial process mainly occurred in seawater and coastal environment sediments [25], invertebrate digestive tracts, thawing permafrost soils, and extreme environments [26] through anaerobic methylators as Sulfate-Reducing Bacteria (SRB) [27 - 30], Iron Reducing Bacteria (IRB) and methanogens $[27,31,32]$. Two-gene cluster, $h g c \mathrm{~A}$ and $h g c \mathrm{~B}$ encode a putative corrinoid protein facilitating methyl transfer and a ferredoxin carrying out corrinoid reduction, were reported to be involved in mercury methylation process [27]. According to Podar et al. 2015, $h g c \mathrm{~A}$ and $h g c \mathrm{~B}$ genes were found in nearly all anaerobic environments but not in aerobic and not in human and mammalian microbiomes, reducing the expected risk of $\mathrm{Hg}$ methylation by microbiomes [26].

Another unrecognized oxidation/methylation pathway in the mercury cycle by anaerobic bacteria as in $D$. desulfuricans ND132 and G. sulphurreducens PCA [17, 33] produces MeHg using dissolved $\mathrm{Hg}$ as their sole $\mathrm{Hg}$ source. Further investigation is required for detecting the reactions involved in and the connection between $\mathrm{Hg}$ methylation, oxidation and produced toxic $\mathrm{MeHg}$ exportation out of cells as $D$. desulfuricans lacks the mer operon system that detoxifies organic/inorganic mercury [17].

Moreover, abiotic $\mathrm{Hg}^{+2}$ methylation carried out chemically [34] with the help of humic and fulvic acids, carboxylic acids, and compounds as fungicides or antifouling agents [11,35]. It was found that sunlight played a minor and slower role in methylation reaction [36].

\subsection{Demethylation Process}

Biotic demethylation occurs simultaneously in the methylation sites as a reverse process [34]. It is catalyzed through reduction [37] or oxidation processes [38]. Aerobic reductive demethylation of $\mathrm{CH}_{3} \mathrm{Hg}^{+}$occurs through mer operon functions (merA and merB) forming $\mathrm{CH}_{4}$ and $\mathrm{Hg}$ [37]. Formed $\mathrm{Hg}$ will be evaporated into the air, and the cycle is repeated [39, 40]. Anaerobic reductive demethylation, Geobacter bemidjiensis Bem is an iron-reducing bacterium capable of simultaneously both methylating $\mathrm{Hg}^{+2}$ and degrading $\mathrm{MeHg}$, due to the the presence of homologues of an organomercurial lyase and a mercuric reductase [41]. Oxidative demethylation occurs in more anaerobic conditions yielding $\mathrm{CO}_{2}$ and small amounts of $\mathrm{Hg}^{+2}$ with an unknown mechanism [38, 39]. Produced $\mathrm{Hg}^{+2}$ may be available for remethylation process or reduction to its vapor form [11]. Both anaerobic methylation and demethylation processes are affected by environmental dissolved organic matter, iron-sulfate biogeochemistry, and $\mathrm{Hg}^{+2}$ concentration [17, 27, 42].

Abiotic demethylation of $\mathrm{MeHg}$ affected by photo-degradation, especially UV-A and UV-B, at a wavelength range of 200-400 nm [11, 43, 44]. A study on Hg cycling found that dissolved MeHg concentration was decreased in daylight and increased in non-daylight suggesting that photo-degradation in water has a major role in methylation/demethylation processes aquatic systems [45].

All mercury forms $\left(\mathrm{Hg}, \mathrm{Hg}^{+2}\right.$, and $\left.\mathrm{CH}_{3} \mathrm{Hg}^{+}\right)$are interconvertible and can be introduced into the aquatic system [8]. Their concentration in the aquatic system depends mainly on reduction, methylation, and demethylation ratio which 
depend on the microbial community [6].

$\mathrm{CH}_{3} \mathrm{Hg}^{+}$had a different pathway as bio-accumulator in the food chain. Its concentration is higher in top food chain organisms due to $\mathrm{CH}_{3} \mathrm{Hg}^{+}$biomagnifications [46]. As $\mathrm{CH}_{3} \mathrm{Hg}^{+}$concentration is higher in predatory animals such as beluga and polar bears than marine mammals which have higher concentrations of $\mathrm{Hg}$ than freshwater fish and overland mammals, due to their higher position in marine food webs [47]. Marine and freshwater fishes are still the main sources of dietary $\mathrm{Hg}$ exposure for humans $[6,47] . \mathrm{CH}_{3} \mathrm{Hg}^{+}$is the main specie absorbed in the gut; it enters the bloodstream and distributes to body tissues and organs [47]. In fish, $\mathrm{CH}_{3} \mathrm{Hg}^{+}$first accumulates in the viscera (kidney, spleen, and liver) and later redistributed to other tissues as muscles and brain tissues. Hence, mammals and birds can demethylate $\mathrm{CH}_{3} \mathrm{Hg}^{+}$. So, a large amount of accumulated $\mathrm{Hg}$ in liver and kidney are found in an inorganic form [47].

\section{MERCURY BIOREMEDIATION}

It is a remediation technique using a wide range of living organisms (algae, fungi, yeasts, plants and bacteria) or their enzymes. Bioremediation is preferred as environmental friendly, promising technique. Microbial remediation using bacteria is widely used as they can be easily cultivated, grow faster and can accumulate metals in different conditions [48 - 51]. Moreover, different Gram-negative and positive bacterial isolates can resist, accumulate, adsorb and transform toxic mercury forms to less toxic forms by different mechanisms. These bacteria are named Mercury Resistant Bacteria (MRB) [8, 12, 48]. Bioremediation using bacterial strains showed promising results, reached 76.4\% compared to other remediation techniques in removing mercury pollutant leached from spent fluorescent lamps [52].

\subsection{Phytoremediation}

Green plants or its associated microorganisms are used to remove or destroy contaminants from the soil. The insertion of bacterial mercury resistance genes as (merP, merC, mer $\mathrm{F}$ and $\operatorname{mer} \mathrm{T})$ encodes for different transporter proteins, (merA) encodes for mercury reductase or (merB) encodes for organomercurial lyase into plant cells after their sequences modification according to preferred plant codons. Genes inserted as mer $\mathrm{B}$ remove organic mercury by protonolysis of $\mathrm{C}-\mathrm{Hg}$ to $\mathrm{Hg}^{+2}$ while merA helps in the reduction of $\mathrm{Hg}^{+2}$ by the formation of volatile elemental mercury $\mathrm{Hg}$ which is then volatilized out of plant cells [53 - 57]. Different plant types and species were engineered as Arabidopsis thaliana as described in Table 1, yellow poplar [58], tobacco [59, 60], peanut [61], salt marsh cordgrass [62], rice [63] and eastern cottonwood [64, 65] that showed successful high resistance levels than their wild types.

Hence, genetically engineered plants can get rid of ionic and organic mercury by phytovolatilization. However, phytovolatilization major concern is the release of mercury vapors back to the environment, but this can be reduced by increasing efficacy of phytoextraction/phytosequestration. This could be achieved by transforming plants with certain

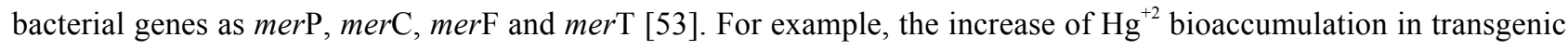
tobacco by expressions of the merP gene producing bacterial Polyphosphate Kinase (PPK) [54, 66].

An MRB Enterobacter strain exhibited a novel property of $\mathrm{Hg}$ immobilization by synthesis of nanoparticle $\mathrm{Hg}$. The strain could intracellularly synthesize Hg nano-particles sized 2-5-nm [67].

Table 1. Effect of different mer genes, inserted and expressed in different regions of $A$. thaliana plant, on mercury phytoremediation.

\begin{tabular}{|c|c|c|c|}
\hline Expression & Inserted gene & Effect on Resistance & References \\
\hline Cytoplasm & mer $B$ & Increase resistance of phenylmercuric acetate PMA to $2 \mu \mathrm{M}$ & {$[157]$.} \\
\hline Cytoplasm & merA & Increase resistance of $\mathrm{Hg}^{+2}$ to $100 \mathrm{Mm}$ & {$[56]$.} \\
\hline Cytoplasm & $m e r A / B$ & Increase resistance of organic and inorganic $\mathrm{Hg}$ to $5-10 \mu \mathrm{M}$ & {$[158]$.} \\
\hline Cell membrane & $m e r P(p p k)$ & Increase resistance of $\mathrm{Hg}^{+2}$ to $10 \mu \mathrm{M}$ & {$[159]$.} \\
\hline Cell membrane & $m e r C$ & Increase resistance of $\mathrm{Hg}^{+2}$ to $10 \mu \mathrm{M}$ & {$[160]$.} \\
\hline Cytoplasm & $m e r E$ & Increase of inorganic and organic- $\mathrm{Hg}$ accumulation & {$[55]$.} \\
\hline
\end{tabular}

\section{MERCURY RESISTANCE MECHANISMS}

To adapt to toxic metals in the environment, bacteria and other organisms have developed different resistance mechanisms as a defense systems against these toxic materials. This defense systems that help bacteria to eliminate toxic materials from their growth medium includes: 
1. Mercury bioaccumulation whether by simultaneous synthesis of mercury as nanoparticles [67] or by $\mathrm{Hg}^{+2}$ binding to carboxyl phosphates, hydroxyl, thio, or pyridine functional groups located on some bacterial cell wall [49] so, mercury is trapped and can't be vaporized back into the environment [67],

2. Sequestration and chelation of mercury using intracellular binding Metallothionein protein [68], a cysteine-rich protein able to bind mercury ions to form Mercury-cysteine complexion or extracellular polysaccharides in the cell wall $[69,70]$ as mercury compounds have high ability to bind with thiols of bacterial cysteine and reduce mercury toxicities [11],

3. Blocking mercury entry into cells through permeability barriers $[11,71]$,

4. Efflux and volatilization to convert toxic ionic mercury, $\mathrm{Hg}^{+2}$, to much less toxic, elemental mercury, $\mathrm{Hg}$ through genetic manner [70], reductase enzymes as those expressed by the help of mercury resistance (mer) operon that will be described later [3, 70, 72] or through cytochrome c oxidase enzymes [73].

For these valuable mechanisms, different bacterial strains and other biological systems were engineered to be used for remediation and monitoring of environmental hazards such as increasing the bioaccumulation of $\mathrm{Hg}^{+2}$ by expression of the bacterial Polyphosphate Kinase (PPK) in transgenic tobacco [66].

\section{COMPONENTS AND FUNCTIONS OF MER OPERON IN MERCURY RESISTANT BACTERIA (MRB)}

All mer determinants (mer operon) are widely distributed by both Horizontal (HGT) and Vertical Gene Transfer (VGT) which explain their presence in different bacterial populations [70]. It was found located on chromosomal DNA [74], mobile elements as plasmids [40, 75], transposons as components of the Tn21 [22, 76] and Tn501 [46], or on integrons [77]. These mer determinants were identified in a wide range of previously isolated gram-negative [78] as seen in Fig. (2) and Gram-positive [79] bacterial strains from clinical [80, 81] and environmental [82, 83] samples. Genes in mer operon express different enzymes that can transform toxic to less toxic mercury forms as organomercuriallyase and mercuric reductase as illustrated in Table 2. In addition to mercury detoxification, some MRB can also detoxify other metals [84].

These mer determinants are classified into two types; narrow-spectrum that detoxifies only inorganic mercury through the main merA gene or broad-spectrum that detoxifies both organic and inorganic mercury through merA and mer $\mathrm{B}$ genes $[8,85,86]$. The mer operon is composed of the operator, promoter, regulator genes, and functional genes such as merR, mer $\mathrm{P}$, mer $\mathrm{T}$, mer $\mathrm{D}$, merA, merF, mer $\mathrm{C}$, mer $\mathrm{E}$, mer $\mathrm{H}$, mer $\mathrm{G}$ and $m e r \mathrm{~B}$. All these genes code for different proteins that participate in the detection, transportation and reduction or methylation of mercury ions $[7,75,87,88]$.

Table 2. All mer operon genes and their expressed proteins.

\begin{tabular}{|c|c|c|c|c|c|}
\hline Gene & $\begin{array}{c}\text { Gene Location in } \\
\text { Operon }\end{array}$ & Protein Encoded & $\begin{array}{c}\text { Protein } \\
\text { Location }\end{array}$ & Function & References \\
\hline $\operatorname{mer} \mathbf{A}$ & $\begin{array}{l}\text { Immediately after } \\
\text { transport genes }\end{array}$ & Mercuric reductase & Cytoplasm & Reduction of $\mathrm{Hg}^{+2}$ to $\mathrm{Hg}$ & {$[8,22]$} \\
\hline mer $\mathrm{B}$ & $\begin{array}{l}\text { Immediately after } \\
\text { transport genes }\end{array}$ & Organomercuriallyase & Cytoplasm & Lysis of $\mathrm{C}-\mathrm{Hg}$ bond & {$[8,99]$. } \\
\hline merF & $\begin{array}{c}\text { May be in plasmid } \\
\text { between merP and merA }\end{array}$ & Transporter protein & Inner membrane & $\begin{array}{l}\text { Narrow and broad spectrum system } \\
\text { transporters of mercuric. }\end{array}$ & {$[90,92]$.} \\
\hline merE & $\begin{array}{c}\text { Downstream of merA and } \\
\text { mer } \mathrm{B}\end{array}$ & Transporter protein & Inner protein & $\begin{array}{c}\text { Uptake of inorganic and organo- } \\
\text { mercurials }(\mathrm{MeHg}) \\
\text { into cytoplasm }\end{array}$ & {$[55,89,69]$} \\
\hline merG & Between merA and merB & $\begin{array}{l}\text { Organomercurial compounds } \\
\text { resistance protein }\end{array}$ & Periplasm & $\begin{array}{l}\text { Resistance to phenyl-mercury by } \\
\text { efflux mechanism } \\
\text { (reduce their cellular permeability) }\end{array}$ & {$[11,89,86]$} \\
\hline merP & Upstream merA & Periplasmic $\mathrm{Hg}^{+2}$ binding protein & Periplasm & Transfer of $\mathrm{Hg}^{+2}$ & {$[8,11,76]$. } \\
\hline merT & Upstream merA & Transporter protein & Inner membrane & $\begin{array}{c}\text { Transporters of mercury in both narrow } \\
\left(\mathrm{Hg}^{+2}\right) \text { and broad (phenyl mercury) } \\
\text { spectrum systems. }\end{array}$ & {$[89,90]$} \\
\hline merD & Downstream merA & Regulator protein & Cytoplasm & Negatively regulates the mer operon & {$[109,110,$.} \\
\hline merC & Upstream merA & Transporter protein & Inner membrane & $\begin{array}{l}\text { Narrow and broad spectrum system } \\
\text { transporters of mercuric. }\end{array}$ & {$[90]$} \\
\hline $\operatorname{mer} \mathbf{R}$ & Before transport genes & Regulator protein & Cytoplasm & Positively regulates the mer operon & $\begin{array}{c}{[11,22,76,89,} \\
106] .\end{array}$ \\
\hline
\end{tabular}


(Table $\square$ ) contd.....

\begin{tabular}{|c|c|c|c|c|c|}
\hline Gene & $\begin{array}{c}\text { Gene Location in } \\
\text { Operon }\end{array}$ & Protein Encoded & $\begin{array}{c}\text { Protein } \\
\text { Location }\end{array}$ & Function & References \\
\hline merH & $\begin{array}{c}\text { Immediately } \\
\text { adjacent to merA }\end{array}$ & $\begin{array}{l}\text { Mercury trafficking protein } \\
\text { (metallochaperone) }\end{array}$ & Cytoplasm & Trafficking of mercury & {$[95,161]$.} \\
\hline merI & Located 3' to merA & Unknown & & $\begin{array}{c}\text { Have no role in mercury resistance or } \\
\text { regulation }\end{array}$ & {$[95,161]$} \\
\hline
\end{tabular}

\section{1. $\mathrm{Hg}^{+2}$ Binding and Transportation Genes}

mer $\mathrm{T}, \operatorname{mer} \mathrm{P}, \operatorname{mer} \mathrm{C}, \operatorname{mer} \mathrm{E}, \operatorname{mer} \mathrm{F}$, and newly discovered $m e r \mathrm{H}$ express different proteins that have different roles in mercury transportation as shown in Fig. (2) [89].

merT, expresses an inner membrane (cytoplasmic) proteins [22], helps in the uptake of organic phenylmercury [90] and inorganic mercury transport into the cytoplasm [91]. MerT protein has three transmembrane regions with cysteine pair located in its first transmembrane region Cys-Cys [90].

merP, expresses a periplasmic protein [22] that has two cysteine residues to help in replacing the nucleophiles $\left(\mathrm{Cl}^{-}\right)$ linked to $\mathrm{Hg}^{+2}$ so, $\mathrm{Hg}^{+2}$ could bind to merP cysteine residues then transferred to other two cysteine residues on merT protein located on cytoplasmic membrane $[8,11,76]$ then passed to other pair of merT's cytosolic cysteines residues. $\mathrm{Hg}^{+2}$ enters the cytoplasmic membrane where cytosolic thiols (cysteines or glutathions) compete with merT's cytosolic cysteines to bind with $\mathrm{Hg}^{+2}$ to be ready for merA activity [11].

$\underline{\text { mer } \mathrm{T}}$ and $\underline{\text { merP } \mathrm{P}}$ deletion from transposon $\mathrm{Tn} 501$ lead to $\mathrm{Hg}^{+2}$ sensitivity while the expression of $\mathrm{Tn} 501 \mathrm{mer} \mathrm{T}$ and merP in the absence of mercuric reductase causes $\mathrm{Hg}^{+2}$ supersensitivity [22]. Moreover, mutations in both merT and mer $\mathrm{P}$ increase $\mathrm{Hg}^{+2}$ concentration required for induction of merA-lacZ transcriptional fusions. So, mer $\mathrm{P}$ is important for $\mathrm{Hg}^{+2}$ resistance [22]. However, Sone and Nakamura et al. showed that absence of merP in presence of other alternative transporters $m e r \mathrm{C}, m e r \mathrm{E}, m e r \mathrm{~F}$ and $m e r \mathrm{~T}$ would increase both inorganic and organic mercury transportation. While the presence of merP with all other transporters did not cause any difference in organic mercury transportation but increased the inorganic transportation [90]. MerE, MerT, MerC and MerF are broad-spectrum mercury transporter proteins that can transport organic phenylmercury and inorganic $\mathrm{Hg}^{+} 2$ into cells [11, 90 - 92].

$\underline{M e r C}$, expresses an inner membrane (cytoplasmic) protein [22], that is involved in both inorganic and organic phenylmercury [90] uptake across the cytoplasmic membrane till it reaches active site reductase [70]. $\mathrm{MerC}$ protein was found to have roles in mercury accumulation in Arabidopsis thaliana [93].

Absence or mutation of merC could show no effects on mercury transportation and resistance in case of presence of mer $\mathrm{T}$ and merP as shown in Tn501 and Tn5053. However, in some bacterial strains when both merT and merP do not exist, $m e r \mathrm{C}$ can act alone as the main $\mathrm{Hg}^{+2}$ transporter [22,76]. Other new findings showed that $m e r \mathrm{C}$ is more preferred in $\mathrm{Hg}^{+2}$ transportation than $m e r \mathrm{E}, \operatorname{mer} \mathrm{F}$ and $m e r \mathrm{~T}$. Moreover, $m e r \mathrm{C}$ was more efficient for designing successful mercurial bioremediation system [90].

$\underline{\text { merF }}$ helps in both organic phenylmercury [90] and inorganic $\mathrm{Hg}^{+2}$ transport across the cytoplasm [11, 92].

$\underline{m e r H}$ expresses a membrane protein and according to Schué, it was able to transport $\mathrm{Hg}^{+2}$ across the inner membrane using its two cysteine residue. Replacing merT gene in an E-coli strain by merH resulted in $\mathrm{Hg}^{+2} \mathrm{MIC}$ reduction, although the strain is still resistant when compared with a control strain which has no transporter proteins [94]. As described by Schelert, a metallochaperone, homolog to C-terminal domain, called TRASH has a role in metal sensing and trafficking that explains $m e r \mathrm{H}$ role in trafficking of $\mathrm{Hg}^{+2}$ to the MerR transcription factor. By non-sense or in-frame gene mutation of $m e r \mathrm{H}$, the new mutant strain was highly sensitive to $\mathrm{Hg}^{+2}$ and analysis of $m e r \mathrm{H}$ deleted operon by mass spectroscopic. They found increased retention of $\mathrm{Hg}^{+2}$ intracellular that explains the low rate of mer operon induction and the need for $\mathrm{mer} \mathrm{H}$ in metal trafficking [95].

$\underline{m e r E}$ is involved in the transport system of inorganic [89] and organic phenylmercury compounds selectively across the membrane [96]. Organomercurial compounds are lipid-soluble and can pass through the cell membrane by simple diffusion [11,97] or are transported inside by merE or mer $\mathrm{G}[98]$. Their transport system is poorly understood [96, 97]. 


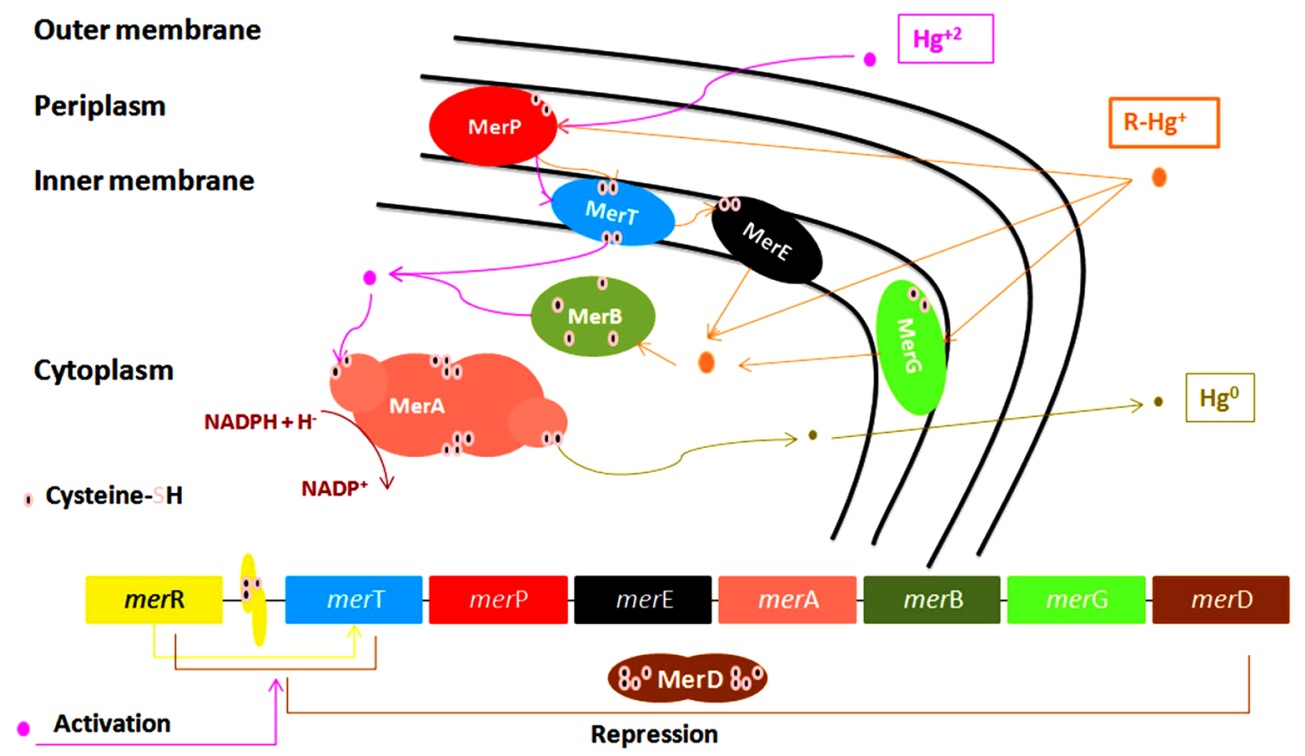

Fig. (2). Model of bacterial mer operan determinants and expressed genes. Organic methylmercury can enter inside cell through merP, T, and E transporter while, phenylmercury transported by merG protein also both may passively diffused inside the cell. Inorganic mercury transported by merP and $\mathrm{T}$ to be reduced by merA(10).

\section{2. mer Detoxification Genes}

$\underline{\text { merA }}$ is the main gene in mer operon encodes for mercuric ion reductase enzyme, which is a flavoprotein catalyzes reduction of $\mathrm{Hg}^{+2}$ into volatile $\mathrm{Hg}$ by using NADPH located in the cytoplasm as source of electrons for the reduction of Flavin Adenine Dinucleotide (FAD) [76, 99, 100]. Hg is released out of the bacteria through cell membrane due to its lipid solubility without efflux system $[11,22,75,76,101]$. The released $\mathrm{Hg}$ back to the environment causes repetition of mercury cycle. To overcome this problem, a new study used an engineered bacteria to express polyphosphate, a chelator for divalent metal, in addition to mer operon determinants to overcome metal volatilization [102], help reducing environmental re-pollution. merA has an amino-terminal domain (NmerA) Fig. (3), which is homologous to merP and contains a pair of cysteines that directly remove $\mathrm{Hg}^{+2}$ from transport proteins cytosolic cysteines to be ready for reduction [11]. Mutations by insertion or deletion in merA cause $\mathrm{Hg}^{+2}$ hypersensitive strains [22].

$\underline{\text { mer } \mathrm{B}}$, codes for organomercurial lyase catalyzes demethylation of organic mercury compounds (alkyl and aryl) via cleavage of its $\mathrm{C}-\mathrm{Hg}$ bond releasing a protonated organic moiety (as methane $\left(\mathrm{CH}_{4}\right)$ in case of $\mathrm{MeHg}$ ) and $\mathrm{Hg}^{+2}$ which is then reduced to $\mathrm{Hg}$ by merA using same NADPH-dependent mechanism [11, 78, 99, 103, 104].

\subsection{Mechanism of Organomercurials Protonolysis by Merb}

Organomercuriallyase acts as a monomer containing four cysteine residues Cys117, Cys 96, Cys 159, and Cys160. Asp99, Cys96, and Cys159 residues of the enzyme and water molecule all are involved in protonolysis reaction [11, 103]. $\mathrm{MeHg}$ forms bond with Cys96, while the Cys159 site is fully reduced then the organic moiety released through two mechanisms, Fig. (4). In mechanism 1; proton from Cys159 transferred to methyl carbon and Cys159 forms covalent bond with $\mathrm{Hg}^{+2}$. In mechanism 2, Cys159 first transfer proton to Asp99 then forms a covalent bond with $\mathrm{Hg}^{+2}$ in presence of methyl group. Asp99 then transfer a proton to the methyl group and the protonated methyl moiety is released. $\mathrm{Hg}^{+2}$ is attached to the enzyme by two sulfurs of Cys96 and Cys159, and oxygen from a water molecule [103]. Organomercuriallyase remains attached to $\mathrm{Hg}^{+2}$ until two solvent thiols separately bind two $\mathrm{Hg}^{+2}$ and removes it [11].

$\underline{m e r G}$ helps in cellular permeability of organomercurial compounds (Phenylmercury) through effluxing [11, 96, 98, 105]. Mutation by merG deletion, phenylmercury resistance was affected however, $\mathrm{Hg}^{+2}$ volatilization activity wasn't affected. So, merG have no role in inorganic mercury compounds detoxification [96]. 


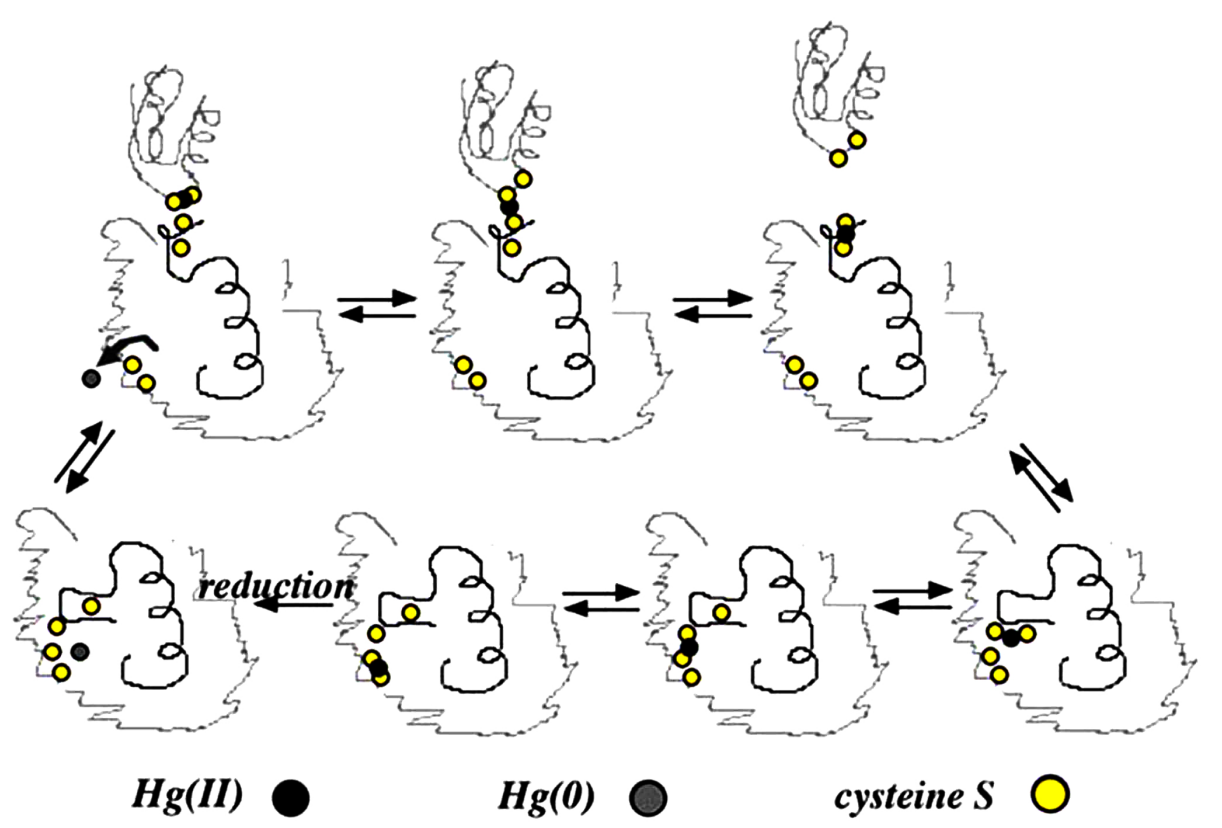

Fig. (3). Illustration for the role of NmerA in $\mathrm{Hg}^{+2}$ removal from transport proteins cytosolic cysteine to be reduced by mercuric reductase into $\mathrm{Hg}(11)$.

\section{4. mer Operon Regulatory Genes}

Regulatory genes are merR and merD [89]. $\underline{\text { mer } \mathrm{R}}$, a regulatory gene encodes a metalloregulatory protein. $\mathrm{It}_{\text {is }} \mathrm{Hg}^{+2}$ dependent transcriptional repressor-activator that can sense metal concentration and control the expression of other functional mer operon genes [11, 106, 107]. It binds with the promoter-operator region (merOP) and positively and negatively regulate mer operon genes expression in presence or absence of $\mathrm{Hg}^{+2}$ respectively $[8,22,75,76,87,106]$. Hg-free-merR (apo-merR) undergoes conformational structure changes upon $\mathrm{Hg}^{+2}$ binding and converted from repression to activation state Hg-merR [108].

$\underline{m e r D}$, a gene encodes for a secondary regulatory protein, present downstream merA [109]. MerD protein is expressed in very small amounts and downregulates the mer operon [110]. Its absence causes an increase in mer operon expression. It binds with the same operator-promoter region (merOP) as MerR [8, 22, 76]. It acts as activation antagonist for MerR function. Invitro experimental showed that, after $\mathrm{Hg}^{+2}$ volatilization by merA, the MerR does not give up its bound $\mathrm{Hg}^{+2}$ quickly causing merA to be active. merA expression should be stopped when $\mathrm{Hg}^{+2}$ is exhausted because mer A has an oxidase activity and produces toxic hydrogen peroxide in the absence of $\mathrm{Hg}^{+2}$ [11].

\section{MER OPERON EVOLUTION, MOBILITY AND DIVERSITY}

mer operon is an ancient system [97] may be located on the chromosome [74] and transferred vertically from parents to offspring or on Mobile Genetic Elements (MGE). DNA parts encode proteins that help in its mobility within bacterial genomes or between bacterial cells, facilitating Horizontal Gene Transfer (HGT) independent on reproduction [46, 77, 106, 111 - 114] so, this flexibility in genome [115] can help bacterial adaptation, social interactions and evolution by transferring good genes for the host as the mer genes [76, 114, 116 - 119]. MGE can help in the rapid spread of rare, spontaneous resistance mutants to a new bacterial population [114]. As plasmid-borne resistance genes can be originated as point mutations in sensitive bacteria and then transferred when they are flanked by short transposons, picked up by Tn3 family transposons or as mobile cassettes by integrons [76, 114, 120]. mer operon as part of different types of group II transposons $[121,122]$ as Tn2, Tn501, pKLH2, pMERPH and Tn5053 in Gram-negative bacteria [11, 97, 121] and Tn5085, Tn5083 [122, 123], and newly identified Tn6294 [123] in Gram-positive bacteria, All of them encode genes for transposition (tnpA) and resolution functions (tnpR) [11, 121 - 124].

Successive exposure to mercury for a long time caused mer operon persistence and transfered between microbes through HGT and to be evolved rapidly and became more complex as merA and species evolved. Evolution happened to adapt with environment, increasing mercury toxicity due to increased industrialization [89] that can explain the 
global distribution of mer determinants and their associated mobile elements between different bacterial strains [11, 97]. So, merA was considered as a biomarker for measuring diversity in $\mathrm{Hg}$ detoxification and mer operon evolution [89, 125].

A recent study on different mer operons of different Bacillus species (as tndMER3, tn6294, and others) isolated from thirteen different countries is a good example for mer diversity, mobility, evolution and horizontal distribution between different Bacillus species worldwide [123].

Genes that express transporter proteins merP and merT were more common to occur in earliest evolved operons which were less complex while, other alternative transporter genes as mer $\mathrm{C}$, mer $\mathrm{F}$, mer $\mathrm{E}$, and mer $\mathrm{H}$ commonly occurred in more complex operons evolved recently. In organomercurial detoxification system, merG gene occurred in more recently evolved operons [89]. Proteins as merE, merC, merP, merD, and merT were also found to be more likely encoded on plasmids than others so, prefer to be transferred horizontally [89].

A recent research depended on sequencing of four different pQBR mercury resistance plasmids showed that mercury resistance transposons Tn5042 were totally similar in the four plasmids except for one base pair of merR in pQBR103 and pQBR44 differed from pQBR55 and pQBR57, indicating that Tn5042 had been transferred between different pQBR plasmids by recombination. They also found that occurrence of pQBR55, pQBR57 and pQBR103 separately in Pseudomonas fluorescens SBW25 host resulted in different response to some environmental factors as $\mathrm{Hg}$ (II) concentration, although similarity in their mer operon suggested the effect of other plasmid-encoded genes [8, 126].

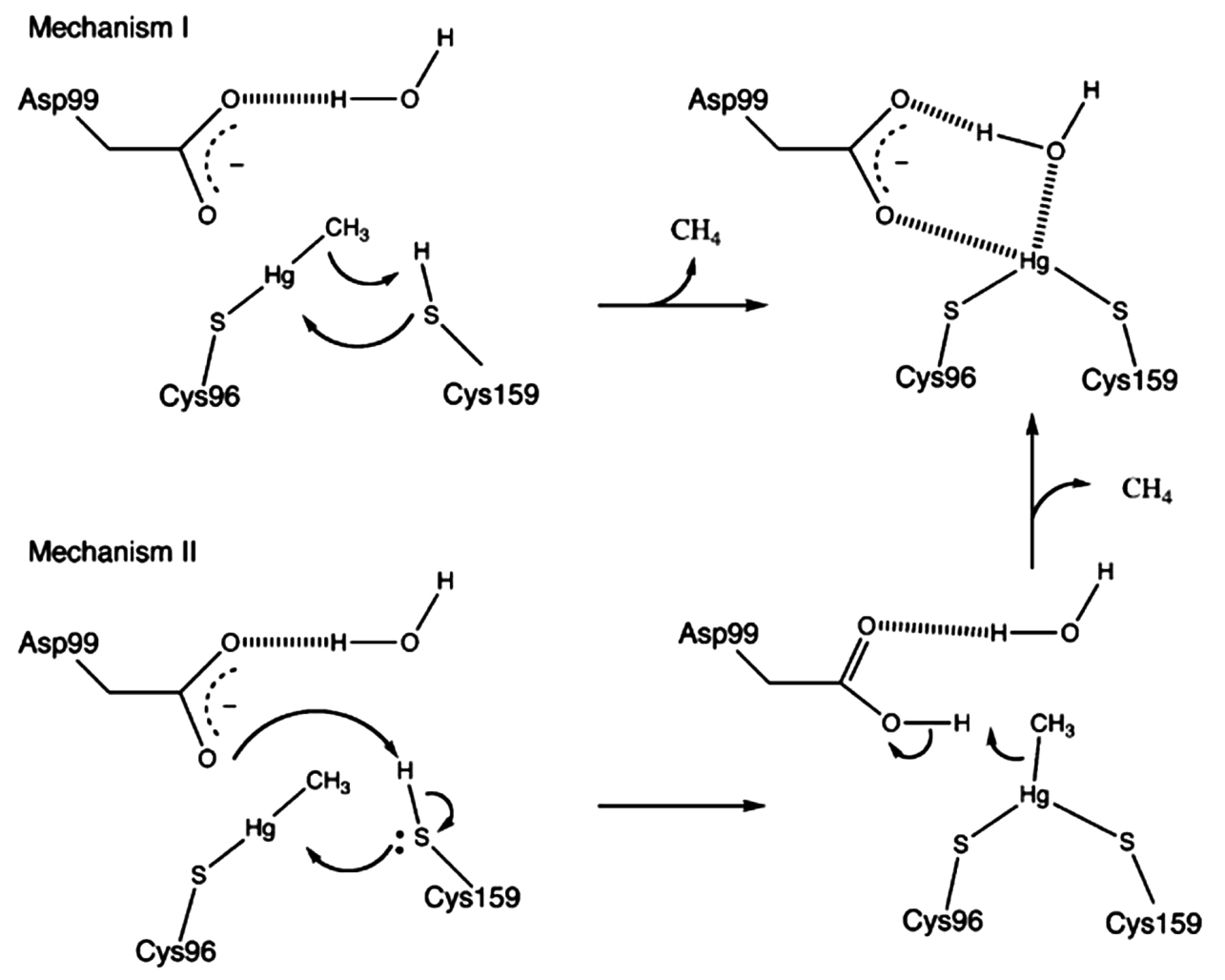

Fig. (4). Mechanisms of MerB catalysis for the Hg-C protonolysis reaction(103). Mechanism 1; Cys159 protonates the methyl group then reacts with $\mathrm{Hg}^{+2}$. Mechanism 2; hydrogen was attached to the sulfur from Cys159 transferred to Asp99 then Asp99 utilized for methyl group protonation.

\subsection{Diversity of mer Operon}

Several variations in structure and organization of mer operons genes are known between both Gram-negative and Gram-positive bacterial strains as in Figs. (5 and 6), for examples: 


\section{Paenibacillus sp. EOA1 Tn6294 (LC015492) \\ Mycobacterium marinum pMM23 (CU462862) \\ Bacillus sp. YR31 $\operatorname{Tn}^{\mathrm{d}} M E R^{3}(\mathrm{LC} 015493)$}

Bacillus megaterium MB1(AB027306, LC069369, $\mathrm{AB} 027307, \mathrm{AB} 022309)$

Bacillus cereus RC607 Tn5084 (AB06636)

Streptomyces pRJ28 (AF222792)

Staphylococcus aureus pI258 (NC_013319)

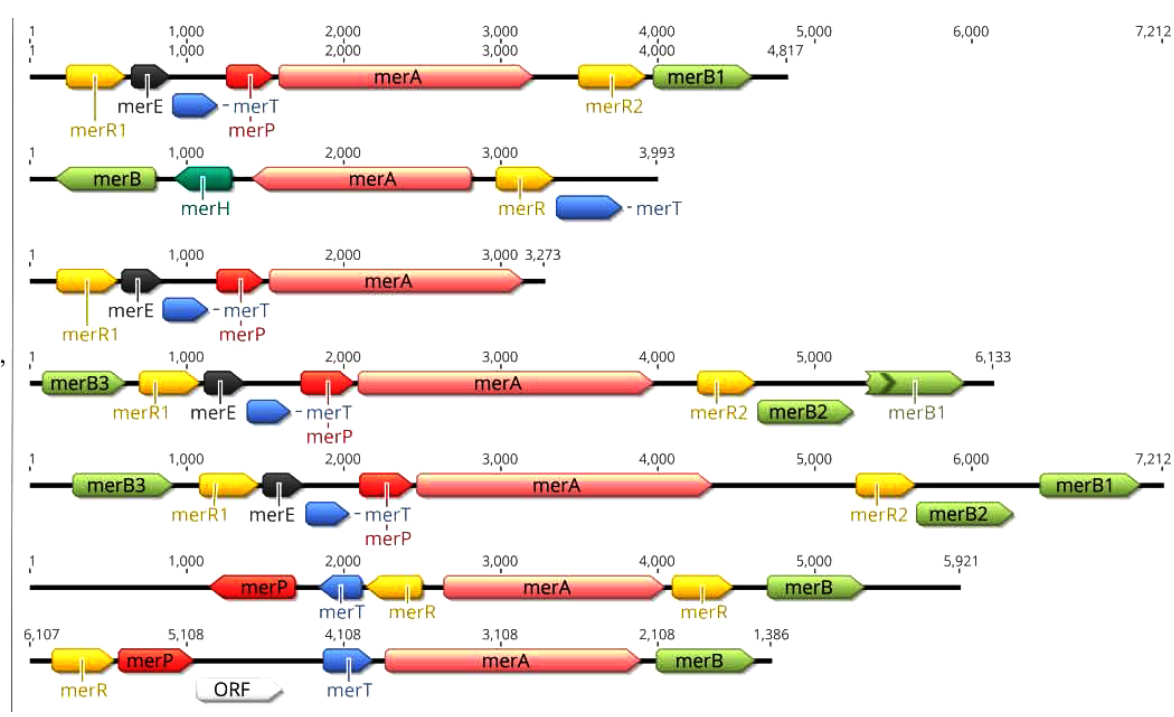

Fig. (5). Diversity mer operons in Gram-positive bacteria. Arrows indicate the gene product translation direction.

1. $m e r \mathrm{~B}$ is more common in Gram-positive mer operons $[123,127,128]$, while $m e r \mathrm{D}$ and $m e r \mathrm{C}$ or $m e r \mathrm{~F}$ are more common in Gram-negative mer operons [11, 76, 97, 129, 130].

2. Narrow-spectrum mer operon genes are highly divergent compared to broad-spectrum operon genes. According to Narita, et al. in certain broad-spectrum mercury resistant Bacillus species, Polymerase Chain Reaction (PCR) product sizes of mer operon genes are identical to that of Bacillus megaterium MB1. However, in narrowspectrum mer operon of certain Bacillus species, PCR product sizes of the targeted merP and merA regions are smaller than merP and merA of the B. megaterium MB1 [131].

3. Three different merB genes were identified in different Bacillus species [127] as in TnMER11-like transposons [123] resistant to different organomercurial compounds and also have multiple merR.

4. Transcription direction of mer $\mathrm{R}$ is same as other mer operon functional genes in Gram-positive bacteria mer operons while, merR transcription is divergent from the structural genes in the high-GC Gram-positive mer operons and Gram-negative operons except Pseudoalteromonas haloplanktis [11, 129, 132, 133].

5. Transposons Tn5084 and Tn5085 are identical in the genetic orientation and contain merB3, merR, merE, mer $\mathrm{T}$, mer $\mathrm{P}$ and merA while, Tn5083 lacks merR2, merB2 and merB1, compared to Tn5084 and Tn5085 [122, 123, 132].

6. Newly identified transposon Tn6294 has one merB. It is the first transposon to carry merA with only one Nterminal mercury binding domain, unlike all other reported broad spectrum Bacillus species that carry duplicate $\mathrm{N}$-domain [123].

7. Tn ${ }^{\mathrm{d}}$ MER3, a newly identified deleted transposon, was similar to the fragment in Bacillus species that carry merRETPA with $>90 \%$ identity to Tn6294 but with no merB and transposonase genes [123].

8. mer operon of Shewanella putrefaciens pMERPH does not have both merD or merR, compared to other Gramnegative bacteria suggesting that merR may be located elsewhere on the plasmid genes [130].

9. Gene position differs from one operon to another as merB present between merA and merD in pDU1358 [133], while in broad spectrum part of Pseudomonas stutzeri pPB located between merR and mer T [134].

10. In Pseudomonas sp. Tn502 and Tn512 mer operon are related to Tn5053 with exception of $m e r \mathrm{C}$ and urf2M in newly recognized Tn502 compared to $m e r F$ in $\operatorname{Tn} 512$ and Tn5053 [129, 135].

\section{CO-RESISTANCE OF MERCURY AND ANTIBIOTICS}

mer operons are often part of group II transposons that carry integrons with multiple antibiotic resistance genes [11]. 
Antibiotics and metals resistance genes are located on the same plasmid [81, 136]. So, mercury exposure can also promote Horizontal Gene Transfer (HGT) of both mercury and antibiotic resistance [91, 125, 137, 138] that explain the increasing challenge in infectious bacteria treatment due to increasing of co-resistance.

Xanthomonas sp.W17 Tn5053(L40585.1)
Uncultured bacteria pSB102 (AJ304453)
Shewanella putrefaciens pMERPH (Z49196.1)
Serratia marcescens pDU1358 (M15049.1, M24940.1)
Pseudomonas stutzeri OX pPB (U81032.1,PSU90263)
Pseudomonas sp.ED23-33 Tn5058 (Y17897.1)
Pseudomonas sp. AW54a Tn512 (EU306744.1)
Pseudomonas aeruginosa RM1 pVS6 Tn502(EU306743.1)
Pseudomonas aeruginosa pVS1 Tn501 (Z00027.1)
Escherichia coli Tn21 (AF071413)

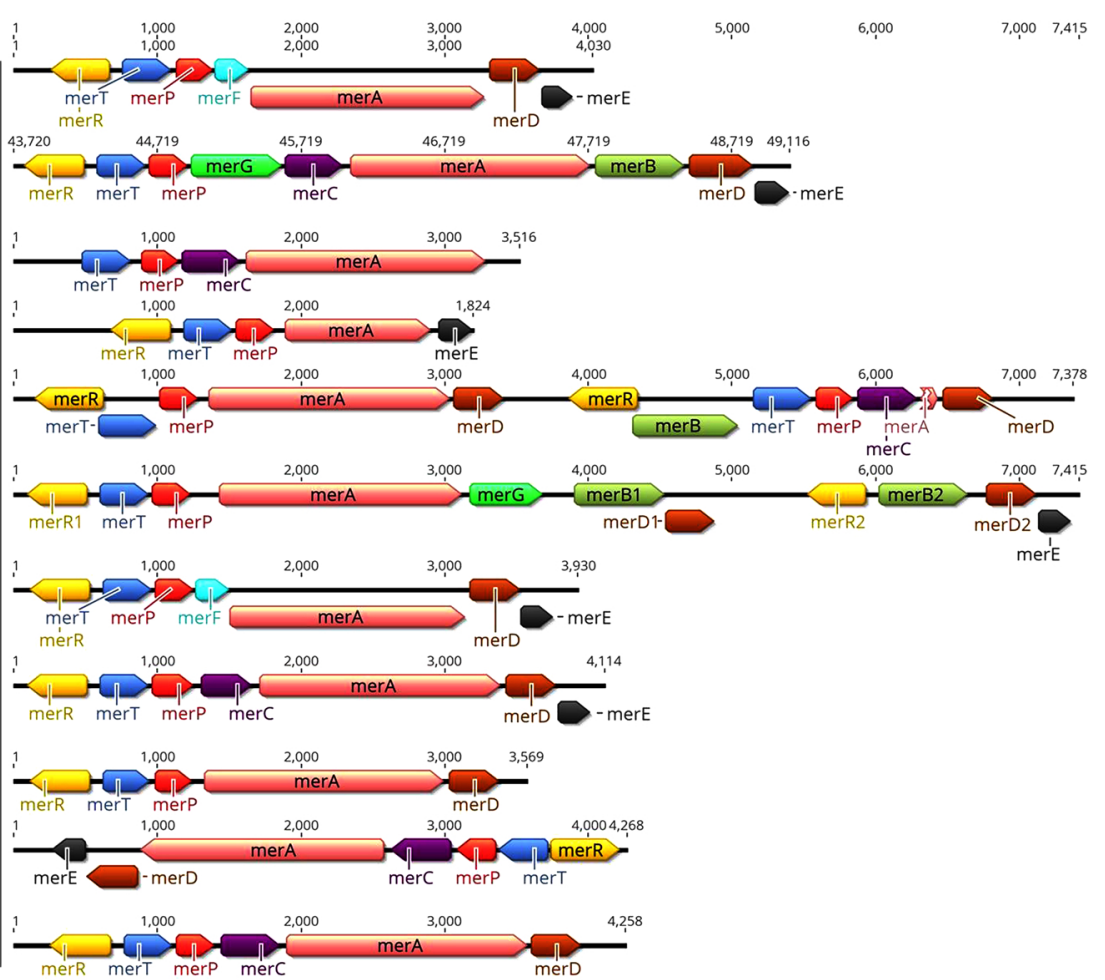

Fig. (6). Diversity of mer operons in Gram-negative bacteria. Arrows indicate the gene product translation direction.

Six adult monkeys were examined for both mercury and antibiotics resistances of different oral and intestinal bacterial strains before and during the installation, and after the replacement of the amalgam fillings. There was an increase in MRB during the 5 weeks after installation and during the 5 weeks after replacement. MRB was also resistant to one or more antibiotics as streptomycin, kanamycin, tetracycline, ampicillin, and chloramphenicol [81]. In a different study groups exposed to amalgam, MRB isolated from their fecal samples was found to be more resistant to antibiotics than MRB of those never exposed to amalgam [77], suggesting that both antibiotic and mercury resistance genes may be genetically linked [81] and contained within the same genetic mobile element [80] specially, the Tn21 family of transposons in which the mer locus is linked to an antibiotic multi-resistance element [77].

A larger scale study by Pal et al., for the co-occurrence of different metals and antibiotic resistance genes of fully sequenced 2522 bacterial genomes and 4582 plasmids as illustrated in Fig. (7), showed that although metal-antibiotic genes co-resistance was found to be rare on plasmid but, the only metal resistance genes commonly co-occurred with antibiotic-resistant genes on plasmids are mercury resistance genes as seen in Fig. (8). Moreover, about $86 \%$ of bacterial genomes contain different metals resistance genes of which 17\% co-resistant with antibiotic resistance. Plasmids and genomes with different metals resistance genes were with high probability of carrying antibiotic resistant genes compared to those without metals resistance genes [138].

\section{MRB DETECTION METHODS}

\subsection{Genotypic (Molecular) Techniques}

\subsubsection{Polymerase Chain Reaction}

Simple PCR Specific DNA sequences of the mer system determinants could be amplified from the genomic DNA of all the isolates from environmental sources using mer determinants designed primers then product can be visualized 
under UV on electrophoresis agarose gel as bands by staining with ethidium bromide [101, 139 - 141].

Real-time Reverse Transcriptase-PCR is used to detect not only the presence but also the mRNA expression of the gene $[87,142]$.

\section{a}

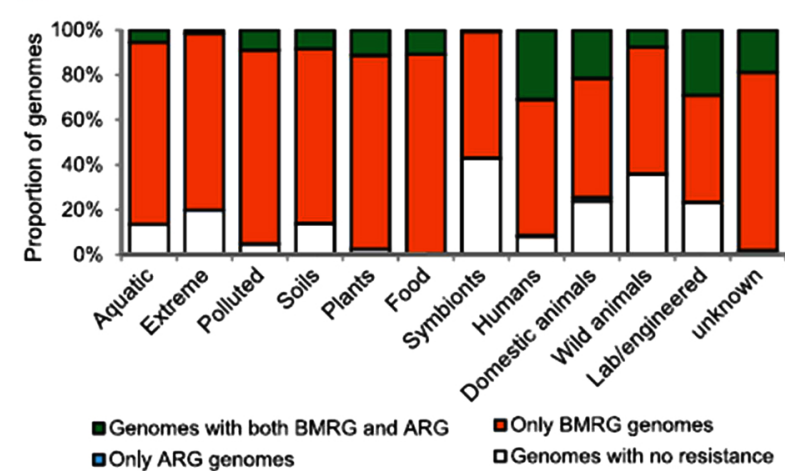

b

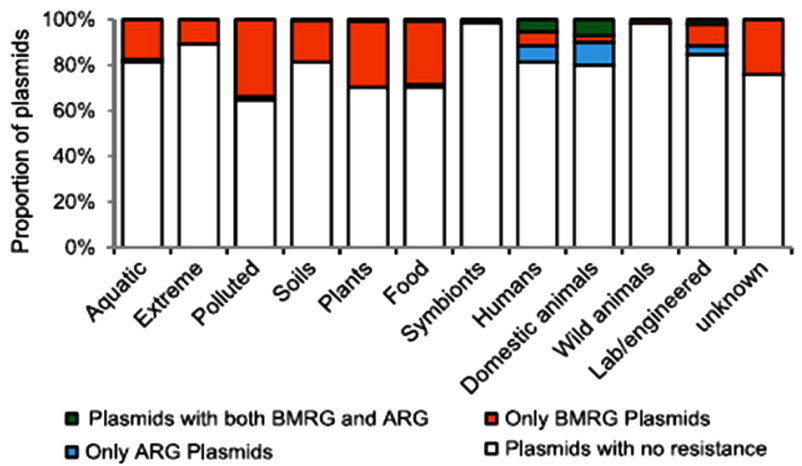

Fig. (7). Overview of the resistance information from (a) 2522 completely sequenced bacterial genomes and (b) 1926 plasmids harboured by those genomes from different environments. (BMRGs) biocide and metal resistance genes. (ARGs) antibiotic resistant genes [138].

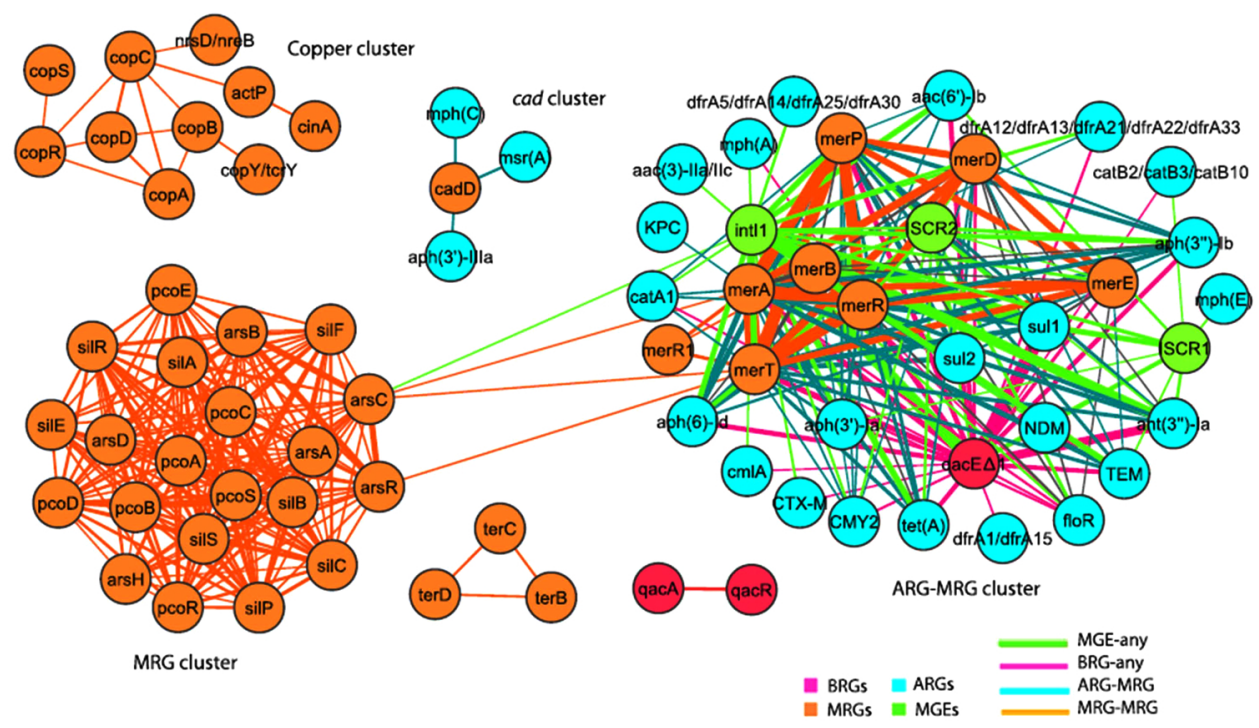

Fig. (8). Co-occurrence network of resistance genes on plasmids [138]. The thickness of each connection between two resistance genes is proportional to their co-occurrence times on the same plasmids. ARGs: Antibiotic Resistance Genes; MRGs: Metal ResistanceGenes; BRGs: Biocide Resistance Genes; MGEs: Mobile Genetic Elements.

\subsubsection{DNA Hybridization Techniques}

mer determinants encoding resistance to $\mathrm{Hg}^{2+}$ as mer $\mathrm{A}$ or other determinants are used as labeled probes in different hybridization procedures for detecting the presence of mer determinants that are complementary to probe nucleotide sequence in mercury resistant bacteria isolated from polluted environments through positive hybridization reaction [139 - 141]. Different hybridization techniques can be applied as Southern [139] and Northern blot hybridization [75], Colony blot hybridization [140, 143], Fluorescent In Situ Hybridization (FISH) [144], and microarray that could be used for detection of different multiple gene at once [145] also Restriction Fragment Length Polymorphism (RFLP) could be used $[139,146]$. 


\subsubsection{DNA Sequencing}

PCR and/or hybridization products can be sequenced to detect its homology to mer determinants [139].

\subsection{Phenotypic Techniques}

\subsubsection{Broth and Agar Methods (Direct Bacterial Growth)}

Processed environmental samples are added into culture media as Luria-Bertani or nutrient agar (broth) supplemented with $10 \mathrm{ppm}$ or greater $\mathrm{HgCl}_{2}$ to detect visible growth (turbidity or colonies) in media with $10 \mathrm{ppm} \mathrm{HgCl}_{2}$ or more. Grown bacteria are considered as MRB [104, 147, 148]. Optical Density (O.D.) in different time ranges at 600 $\mathrm{nm}$ can be measured to detect the growth pattern of tested microorganism in presence of mercury at constant conditions $[80,149]$.

\subsubsection{Hg Utilization (Removal/Reduction) Rate}

As only mercury resistant strains can utilize $\mathrm{Hg}$ and volatilize it, so the rate of $\mathrm{Hg}$ lose from the aqueous media was much higher when the cells are induced by growth in $\mathrm{HgCl}_{2}$ [150]. Tested environmental samples are inoculated in aqueous growth medium supplemented with known concentration of $\mathrm{HgCl}_{2}$ and incubated for $24 \mathrm{hrs}$ at $37 \mathrm{C}$. After centrifugation, the remaining concentration of mercury present in supernatant is measured using the Atomic Absorption Mercury Analyzer and compared to initial known concentration of $\mathrm{Hg}^{+2}$ to calculate its removal rate [83, 149].

Moreover, about $1 \mathrm{ml}$ samples are taken every $4 \mathrm{hrs}$ and centrifuged. Then, remaining $\mathrm{Hg}$ concentration is measured in supernatants after processing. $\mathrm{Hg}^{+2}$ concentrations are calculated by measuring absorbance at OD600 using standard curve. Then, the initial and the final $\mathrm{Hg}^{+2}$ concentrations can be determined and reduction rates will be calculated [87].

\subsubsection{Hg Volatilization Assay}

The ability of bacteria to volatilize mercury from added mercuric chloride is a common mercury resistance mechanism by mer genes [150]. So, volatilization can be determined by using mercury vapor analyzer [75] or other atomic absorption spectrometry [78, 151], radioactive assay or using sensitive film containing $\mathrm{Ag}^{+}$as $\mathrm{TEM}_{\text {photography }}$ film (X-ray film) which forms foggy areas due to reduction of the $\mathrm{Ag}^{+}$emulsion of the film by the mercury vapor [148, $151]$.

\subsubsection{Mercuric Reductase (MR) Activity}

MR activity measured depending on $\mathrm{Hg}^{+2}$ reduction mechanism by the enzyme in presence of NADPH. $\mathrm{Hg}^{2+}$ forms a complex with two cysteines of the enzyme active site. NADPH transfers a proton to FAD forming FADH'. The resulting $\mathrm{FADH}^{-}$then reduces $\mathrm{Hg}^{2+}$ into $\mathrm{Hg}$, and oxidizes back into a FAD. After reduction, the mercury is then released from the enzyme as a volatile vapor [152].

The MR activity was determined by different methods

1. Fluorimetric measurements by oxidation of fluorescent NADPH to the non-fluorescent NADP ${ }^{+}$due to the reduction of $\mathrm{Hg}^{+2}$ to $\mathrm{Hg}$ at specific wave lengths [144].

2. MR assays by measuring Mercury-dependent NADPH oxidation using a UV-visible spectrophotometer [153, 154] as NADPH increases the activity of MR while NADP+ has no effect on activity [154].

3. Determination of the remaining amount of NADPH by titration using phenazine methosulfate to produce visible formazan. The concentration of formed formazan is detected Spectrophotometric. As enzyme activity is related to the remaining amount of NADPH and the produced amount of formazan [155].

\subsubsection{Biosorption Experiments}

Analysis of control and inoculated samples for metal adsorption by inductively coupled plasma optical emission spectroscopy [156].

\section{CONCLUSION}

Industrialization has a great threat to the environmental mercury contamination already spread in the atmosphere, 
soil and water systems. Mercury causes more damage when reached to humans and animals. So, mercury usage should be restricted more to reduce its pollution. mer genes enable bacteria to convert the toxic organic or inorganic mercury forms to less toxic forms helping in mercury bioremediation as the most environmental friendly, safe and effective remediation technique.

The main mer operon genes are the mer $\mathrm{B}$ and merA genes both can help bacteria to detoxify both organic mercurial compounds and inorganic mercury. $\underline{\operatorname{merA}}$, is a mercuric ion reductase enzyme, catalyzes the reduction of $\mathrm{Hg}^{+2}$ into volatile $\mathrm{Hg}$. mer $\mathrm{B}$, codes for organomercurial lyase catalyzes demethylation of organic mercury compounds. mer $\mathrm{T}$, mer $\mathrm{P}$, mer $\mathrm{C}$, mer $\mathrm{E}, \operatorname{mer} \mathrm{F}$, and mer $\mathrm{H}$ express different transporter proteins. mer $\mathrm{G}$ helps in cellular effluxing of organomercurial compounds (Phenylmercury). merR encodes for a metalloregulatory protein, it is $\mathrm{Hg}^{+2} \mathrm{dependent}$ transcriptional repressor-activator that can sense metal concentration and control the expression of other functional mer operon genes. Evolution and diversity in structure and organization of mer genes between different Gram-negative and Gram-positive strains affects their resistance ability as the transporter merP and mer $\mathrm{T}$ genes were more common to occur in earliest evolved less complex operons while, other transporter genes as mer $\mathrm{C}$, mer $\mathrm{F}$, merE, merH and effluxing merG gene are commonly occurred in recently evolved, more complex operons [89].

Bacteria harboring the mer determinants can be genetically modified to code for resistance to other toxicants as toxic metals and be used during extreme environmental different conditions. mer determinants could be transferred into a new genetically engineered recipient suitable biological system (plant, bacteria or algae) to help in mercury remediation after removing undesired genes or adding genes to increase system harmony. Although mer system is highly understood mercury cycle in anaerobic conditions specially $\mathrm{MeHg}$ formation mechanism that prefers anoxic conditions is incompletely understood and requires more investigations as $\mathrm{MeHg}$ is the most bioaccumulative toxic form and understanding the anaerobic system will help in $\mathrm{MeHg}$ bioremediation.

\section{CONFLICTS OF INTEREST}

The authors declare no conflict of interest, financial or otherwise.

\section{CONSENT FOR PUBLICATION}

Not applicable

\section{ACKNOWLEDGEMENTS}

The manuscript was drafted by Dr. Martha M. Naguib and revised and approved by Dr. Ahmed O. El-Gendy, Dr. Ahmed S. Khairalla respectively.

\section{REFERENCES}

[1] Report IT. Heavy Metals "- A meaningless term ? (IUPAC Technical Report). 2002; 74(5): $793-807$.

[2] Montuelle B, Latour X, Volat B, Gounot AM. Toxicity of heavy metals to bacteria in sediments. Bull Environ Contam Toxicol 1994; 53(5): $753-8$. [http://dx.doi.org/10.1007/BF00196950] [PMID: 7833613]

[3] Nisa M, Coral Ü, Korkmaz H, Arikan B, Coral G. Plasmid mediated heavy metal resistances in Enterobacter spp. In: isolated from Sofulu landfill. in Adana, Turkey. Growth (Lakeland). 2005; 55: pp. (3)175-9.

[4] Nies DH. Microbial heavy-metal resistance. Appl Microbiol Biotechnol 1999; 51(6): 730-50. [http://dx.doi.org/10.1007/s002530051457] [PMID: 10422221]

[5] Wedepohl KH. The composition of the continental crust. Geochim Cosmochim Acta 1995; 59(7): $1217-32$. [http://dx.doi.org/10.1016/0016-7037(95)00038-2]

[6] Figueiredo NLL, Areias A, Mendes R, Canário J, Duarte A, Carvalho C. Mercury-resistant bacteria from salt marsh of Tagus Estuary: the influence of plants presence and mercury contamination levels. J Toxicol Environ Health A 2014; 77(14-16): 959-71. [http://dx.doi.org/10.1080/15287394.2014.911136] [PMID: 25072727]

[7] Brooks S, Moore C, Lew D, Lefer B, Huey G, Tanner D. Temperature and sunlight controls of mercury oxidation and deposition atop the Greenland ice sheet. . Atmos Chem Phys 2011; 11(16): 8295-306. [http://dx.doi.org/10.5194/acp-11-8295-2011]

[8] Dash HR, Das S. Bioremediation of mercury and the importance of bacterial mer genes. Int Biodeterior Biodegradation 2012; 75: 207-13. [http://dx.doi.org/10.1016/j.ibiod.2012.07.023] 
[9] Keating MH, Beauregard D, Benjey WG, et al. Mercury Study Report to Congress Volume II: An Inventory of Anthropogenic Mercury Emissions in the United States. United States Environmental Protection Agency 1998. EPA-452/R-:1-181.

[10] Dash HR, Das S. International biodeterioration \& biodegradation bioremediation of mercury and the importance of bacterial mer genes. Int Biodeterior Biodegradation 2012; 75: 207-13.

[http://dx.doi.org/10.1016/j.ibiod.2012.07.023]

[11] Barkay T, Miller SM, Summers AO. Bacterial mercury resistance from atoms to ecosystems. FEMS Microbiol Rev 2003; 27(2-3): 355-84. [http://dx.doi.org/10.1016/S0168-6445(03)00046-9] [PMID: 12829275]

[12] Wang Q, Kim D, Dionysiou DD, Sorial Ga, Timberlake D. Sources and remediation for mercury contamination in aquatic systems - A literature review. Environ Pollut 2004; 131(2): 323-36. [http://dx.doi.org/10.1016/j.envpol.2004.01.010] [PMID: 15234099]

[13] Smith T, Pitts K, McGarvey JA, Summers AO. Bacterial oxidation of mercury metal vapor, Hg(0). Appl Environ Microbiol 1998; 64(4): 1328-32. [PMID: 9546169]

[14] Lindqvist O, Rodhe H. Atmospheric mercury-A review. Tellus B Chem Phys Meterol 1985; 37(3): 136-59. [http://dx.doi.org/10.3402/tellusb.v37i3.15010]

[15] Keeler G, Glinsorn G, Pirrone N. Particulate mercury in the atmosphere: Its significance, transport, transformation and sources. Water Air Soil Pollut 1995; 80(1-4): 159-68. [http://dx.doi.org/10.1007/BF01189664]

[16] Munthe J, McElroy WJ. Some aqueous reactions of potential importance in the atmospheric chemistry of mercury. Atmos Environ Part A 1992; 26(4): 553-7. [http://dx.doi.org/10.1016/0960-1686(92)90168-K]

[17] Matthew J, Colomboa JH, John R. Reinfeldera, Tamar Barkayb, Nathan Yeea. Anaerobic oxidation of Hg(0) and methylmercury formation by desulfovibrio desulfuricans ND132. Geochim Cosmochim Acta 2013; 112: 166-77. [http://dx.doi.org/10.1016/j.gca.2013.03.001]

[18] Allard B, Arsenie I. Abiotic reduction of mercury by humic substances in aquatic system - An important process for the mercury cycle. Water Air Soil Pollut 1991; 56(1): 457-64 [http://dx.doi.org/10.1007/BF00342291]

[19] Colombo MJ, Ha J, Reinfelder JR, Barkay T, Yee N. Oxidation of $\mathrm{Hg}(0)$ to $\mathrm{Hg}(\mathrm{II})$ by diverse anaerobic bacteria. Chem Geol 2014; 363: 334-40. [http://dx.doi.org/10.1016/j.chemgeo.2013.11.020]

[20] Zheng W, Liang L, Gu B. Mercury reduction and oxidation by reduced natural organic matter in anoxic environments. Environ Sci Technol 2012; 46(1): 292-9. [http://dx.doi.org/10.1021/es203402p] [PMID: 22107154]

[21] Gu B, Bian Y, Miller CL, Dong W, Jiang X, Liang L. Mercury reduction and complexation by natural organic matter in anoxic environments Proc Natl Acad Sci USA 2011; 108(4): 1479-83. [http://dx.doi.org/10.1073/pnas.1008747108] [PMID: 21220311]

[22] Hamlett NV, Landale EC, Davis BH, Summers AO. Roles of the Tn21 merT, merP, and merC gene products in mercury resistance and mercury binding. J Bacteriol 1992; 174(20): 6377-85. [http://dx.doi.org/10.1128/jb.174.20.6377-6385.1992] [PMID: 1328156]

[23] Erie L. Mechanistic steps in the photoreduction of mercury in natural waters. 1994; 9697(1993).

[24] Skogerboe RK, Wilson SA. Reduction of ionic species by fulvic acid. Anal Chem 1981; 53(2): 228-32. [http://dx.doi.org/10.1021/ac00225a023]

[25] 2013

[26] Podar M, Gilmour CC, Brandt CC, et al. Global prevalence and distribution of genes and microorganisms involved in mercury methylation. Sci Adv 2015; 1(9): e1500675. [http://dx.doi.org/10.1126/sciadv.1500675] [PMID: 26601305]

[27] Parks JM, Johs A, Podar M, et al. The genetic basis for bacterial mercury methylation. Science 2013; 339(6125): 1332-5. [http://dx.doi.org/10.1126/science.1230667] [PMID: 23393089]

[28] Sedimentt AE. Principal methylators 1985; 50(2): 498-502.

[29] Wood JM, Kennedy FS, Rosen CG. Synthesis of methyl-mercury compounds by extracts of a methanogenic bacterium. Nature 1968; 220(5163): 173-4. [http://dx.doi.org/10.1038/220173a0] [PMID: 5693442]

[30] Choi SC, Chase T, Bartha R. Metabolic pathways leading to mercury methylation in Desulfovibrio desulfuricans LS. Appl Environ Microbiol 1994; 60(11): 4072-7.

[PMID: 16349435] 
[31] Hamelin S, Amyot M, Barkay T, Wang Y, Planas D. Methanogens: Principal methylators of mercury in lake periphyton. Environ Sci Technol 2011; 45(18): 7693-700. [http://dx.doi.org/10.1021/es2010072] [PMID: 21875053]

[32] Kerin EJ, Gilmour CC, Roden E, Suzuki MT, Coates JD, Mason RP. Mercury methylation by dissimilatory iron-reducing bacteria. Appl Environ Microbiol 2006; 72(12): 7919-21. [http://dx.doi.org/10.1128/AEM.01602-06] [PMID: 17056699]

[33] $\mathrm{Hu} \mathrm{H,} \mathrm{Lin} \mathrm{H,} \mathrm{Zheng} \mathrm{W,} \mathrm{et} \mathrm{al.} \mathrm{Oxidation} \mathrm{and} \mathrm{methylation} \mathrm{of} \mathrm{dissolved} \mathrm{elemental} \mathrm{mercury} \mathrm{by} \mathrm{anaerobic} \mathrm{bacteria.} \mathrm{Nat} \mathrm{Geosci} \mathrm{2013;} \mathrm{6(9):} \mathrm{751-4.}$ [http://dx.doi.org/10.1038/ngeo1894]

[34] Li Y, Cai Y. Progress in the study of mercury methylation and demethylation in aquatic environments. Chin Sci Bull 2013; 58(2): 177-85. [http://dx.doi.org/10.1007/s11434-012-5416-4]

[35] Cerrati G, Bernhard M, Weber JH. Model reactions for abiotic mercury (II) methylation: Kinetics of methylation of mercury (II) by mono $\square$, di $\square$, and tri $\square$ methyltin in seawater. Appl Organomet Chem 1992; 6(7): 587-95. [http://dx.doi.org/10.1002/aoc.590060705]

[36] Li Y, Yin Y, Liu G, et al. Estimation of the major source and sink of methylmercury in the Florida Everglades. Environ Sci Technol 2012; 46(11): 5885-93.

[http://dx.doi.org/10.1021/es204410x] [PMID: 22536798]

[37] Begley TP, Walts AE, Walsh CT. Bacterial organomercurial Lyase: Over production, Isolation, and char acterization? 1986(1982); 7186-92.

[38] Oremland RS, Culbertson CW, Winfrey MR. Methylmercury decomposition in sediments and bacterial cultures: Involvement of methanogens and sulfate reducers in oxidative demethylation. Appl Environ Microbiol 1991; 57(1): 130-7. [PMID: 16348388]

[39] Schaefer JK, Letowski J, Barkay T. mer-mediated resistance and volatilization of Hg (II) under anaerobic conditions. Geomicrobiol J 2002; 19(1): 87-102.

[http://dx.doi.org/10.1080/014904502317246192]

[40] Summers AO, Silver S. Mercury resistance in a plasmid-bearing strain of Escherichia coli. J Bacteriol 1972; 112(3): 1228-36. [PMID: 4565536]

[41] Lu X, Liu Y, Johs A, et al. Anaerobic mercury methylation and demethylation by geobacter bemidjiensis Bem. Environ Sci Technol 2016; 50(8): 4366-73.

[http://dx.doi.org/10.1021/acs.est.6b00401] [PMID: 27019098]

[42] Tjerngren I, Karlsson T, Björn E, Skyllberg U. Potential Hg methylation and MeHg demethylation rates related to the nutrient status of different boreal wetlands. Biogeochem 2012; 108(1): 335-50. [http://dx.doi.org/10.1007/s10533-011-9603-1]

[43] Suda I, Suda M, Hirayama K. Degradation of methyl and ethyl mercury by singlet oxygen generated from sea water exposed to sunlight or ultraviolet light. Arch Toxicol 1993; 67(5): 365-8. [http://dx.doi.org/10.1007/BF01973709] [PMID: 8368946]

[44] Seller P, Kelly CA, Rudd JWM, MacHutchon AR. Photodegradation of methylmercury in lakes. Nature 1996; 380(6576): 694-7. [http://dx.doi.org/10.1038/380694a0]

[45] Naftz DL, Cederberg JR, Krabbenhoft DP, Beisner KR, Whitehead J, Gardberg J. Diurnal trends in methylmercury concentration in a wetland adjacent to Great Salt Lake, Utah, USA. Chem Geol 2011; 283(1-2): 78-86. [http://dx.doi.org/10.1016/j.chemgeo.2011.02.005]

[46] Nascimento AM, Chartone-Souza E. Operon mer: Bacterial resistance to mercury and potential for bioremediation of contaminated environments. Genet Mol Res 2003; 2(1): 92-101. [PMID: 12917805]

[47] Braune B, Chételat J, Amyot M, et al. Mercury in the marine environment of the Canadian Arctic: review of recent findings. Sci Total Environ 2015; 509-510: 67-90.

[http://dx.doi.org/10.1016/j.scitotenv.2014.05.133] [PMID: 24953756]

[48] Dixit R, Wasiullah EY, Malaviya D, et al. Bioremediation of heavy metals from soil and aquatic environment: An overview of principles and criteria of fundamental processes. Sustainability $2015 ; 7(2): 2189-212$. [http://dx.doi.org/10.3390/su7022189]

[49] Deng X, Wang P. Isolation of marine bacteria highly resistant to mercury and their bioaccumulation process. Bioresour Technol 2012; 121: 342-7. [http://dx.doi.org/10.1016/j.biortech.2012.07.017] [PMID: 22864169]

[50] Rizwan M, Singh M, Mitra CK, Morve RK. Ecofriendly application of nanomaterials: Nanobioremediation. J Nanoparticles 2014; $2014: 7$. [http://dx.doi.org/10.1155/2014/431787]

[51] McCarthy D, Edwards GC, Gustin MS, Care A, Miller MB, Sunna A. An innovative approach to bioremediation of mercury contaminated soils from industrial mining operations. Chemosphere 2017; 184: 694-9. [http://dx.doi.org/10.1016/j.chemosphere.2017.06.051] [PMID: 28633064] 
[52] Elekes CC, Busuioc G. The mycoremediation of metals polluted soils using wild growing species of mushrooms. Jul 22; 2010; pp. In: In Proceedings of the 7th WSEAS international conference on Latest trands on Eng Educ, Corfu Island Greece 2010; $36-9$.

[53] Wang J, Feng X, Anderson CWN, Xing Y, Shang L. Remediation of mercury contaminated sites - A review. J Hazard Mater 2012; 221-222: $1-18$. [http://dx.doi.org/10.1016/j.jhazmat.2012.04.035] [PMID: 22579459]

[54] Ruiz ON, Daniell H. Genetic engineering to enhance mercury phytoremediation. Curr Opin Biotechnol 2009; 20(2): 213-9. [http://dx.doi.org/10.1016/j.copbio.2009.02.010] [PMID: 19328673]

[55] Sone Y, Nakamura R, Pan-Hou H, Sato MH, Itoh T, Kiyono M. Increase methylmercury accumulation in Arabidopsis thaliana expressing bacterial broad-spectrum mercury transporter MerE. AMB Express 2013; 3(1): 52. [http://dx.doi.org/10.1186/2191-0855-3-52] [PMID: 24004544]

[56] Rugh CL, Wilde HD, Stack NM, Thompson DM, Summers AO, Meagher RB. Mercuric ion reduction and resistance in transgenic Arabidopsis thaliana plants expressing a modified bacterial merA gene. Proc Natl Acad Sci USA 1996; 93(8): 3182-7. [http://dx.doi.org/10.1073/pnas.93.8.3182] [PMID: 8622910]

[57] Bizily SP, Rugh CL, Summers AO, Meagher RB. Phytoremediation of methylmercury pollution: merB expression in Arabidopsis thaliana confers resistance to organomercurials. Proc Natl Acad Sci USA 1999; 96(12): 6808-13. [http://dx.doi.org/10.1073/pnas.96.12.6808] [PMID: 10359794]

[58] Rugh CL, Senecoff JF, Meagher RB, Merkle SA. Development of transgenic yellow poplar for mercury phytoremediation. Nat Biotechnol 1998; 16(10): 925-8. [http://dx.doi.org/10.1038/nbt1098-925] [PMID: 9788347]

[59] He YK, Sun JG, Feng XZ, Czakó M, Márton L. Differential mercury volatilization by tobacco organs expressing a modified bacterial merA gene. Cell Res 2001; 11(3): 231-6. [http://dx.doi.org/10.1038/sj.cr.7290091] [PMID: 11642409]

[60] Ruiz ON, Hussein HS, Terry N, Daniell H. Phytoremediation of organomercurial compounds via chloroplast genetic engineering. Plant Physiol 2003; 132(3): 1344-52.

[http://dx.doi.org/10.1104/pp.103.020958] [PMID: 12857816]

[61] Yang H, Nairn J, Ozias-Akins P, Ozias-akins P. Transformation of peanut using a modified bacterial mercuric ion reductase gene driven by an actin promoter from Arabidopsis thaliana. J Plant Physiol 2003; 160(8): 945-52. [http://dx.doi.org/10.1078/0176-1617-01087] [PMID: 12964870]

[62] Czakó M, Feng X, He Y, Liang D, Márton L. Transgenic Spartina alterniflora for phytoremediation. Environ Geochem Health 2006; 28(1-2): 103-10. [http://dx.doi.org/10.1007/s10653-005-9019-8] [PMID: 16528587]

[63] Heaton AC, Rugh CL, Kim T, Wang NJ, Meagher RB. Toward detoxifying mercury-polluted aquatic sediments with rice genetically engineered for mercury resistance. Environ Toxicol Chem 2003; 22(12): 2940-7. [http://dx.doi.org/10.1897/02-442] [PMID: 14713034]

[64] Che D, Meagher RB, Heaton AC, Lima A, Rugh CL, Merkle SA. Expression of mercuric ion reductase in Eastern cottonwood (Populus deltoides) confers mercuric ion reduction and resistance. Plant Biotechnol J 2003; 1(4): 311-9. [http://dx.doi.org/10.1046/j.1467-7652.2003.00031.x] [PMID: 17163907]

[65] Lyyra S, Meagher RB, Kim T, et al. Coupling two mercury resistance genes in Eastern cottonwood enhances the processing of organomercury. Plant Biotechnol J 2007; 5(2): 254-62. [http://dx.doi.org/10.1111/j.1467-7652.2006.00236.x] [PMID: 17309680]

[66] Nagata T, Ishikawa C, Kiyono M, Pan-Hou H. Accumulation of mercury in transgenic tobacco expressing bacterial polyphosphate. Biol Pharm Bull 2006; 29(12): 2350-3. [http://dx.doi.org/10.1248/bpb.29.2350] [PMID: 17142961]

[67] Sinha A, Khare SK. Mercury bioaccumulation and simultaneous nanoparticle synthesis by Enterobacter sp. cells. Bioresour Technol 2011; 102(5): 4281-4. [http://dx.doi.org/10.1016/j.biortech.2010.12.040] [PMID: 21216593]

[68] Kretsinger RH, Uversky VN, Permyakov EA. Encyclopedia of Metalloproteins. Springer 2013. [http://dx.doi.org/10.1007/978-1-4614-1533-6]

[69] Baldi F, Pepi M, Filippelli M. Methylmercury resistance in desulfovibrio desulfuricans strains in relation to methylmercury degradation. Appl Environ Microbiol 1993; 59(8): 2479-85. [PMID: 16349013]

[70] Bhakta V, Balkrishna M, Thakuri C. Bacterial mer operon-mediated detoxification of mercurial compounds: Ashort review. Arch Microbiol $2011 ; 837-44$.

[71] Pan-Hou HS, Nishimoto M, Imura N. Possible role of membrane proteins in mercury resistance of Enterobacter aerogenes. Arch Microbiol $1981 ; 130(2): 93-5$

[http://dx.doi.org/10.1007/BF00411057] [PMID: 6459062] 
[72] Dash HR, Das S. Bioremediation of mercury and the importance of bacterial mer genes. Int Biodeterior Biodegradation 2012; 75: 207-13. [http://dx.doi.org/10.1016/j.ibiod.2012.07.023]

[73] Sugio T, Komoda T, Okazaki Y, Takeda Y, Nakamura S, Takeuchi F. Volatilization of metal mercury from Organomercurials by highly mercury-resistant Acidithiobacillus ferrooxidans MON-1. Biosci Biotechnol Biochem 2010; 74(5): 1007-12. [http://dx.doi.org/10.1271/bbb.90888] [PMID: 20460735]

[74] Zeng XX, Tagn JX, Jiang P, Liu H W, Dai Z-mM, Liu X-dD. Isolation, characterization and extraction of mer gene of Hg ${ }^{2+}$ resisting strain D2. Trans Nonferrous Met Soc China 2010; 20(50621063): 507-12. [English Edition]. [http://dx.doi.org/10.1016/S1003-6326(09)60170-9]

[75] Schelert J, Dixit V, Hoang V, Simbahan J, Drozda M, Blum P. Occurrence and characterization of mercury resistance in the hyperthermophilic archaeon Sulfolobus solfataricus by use of gene disruption. J Bacteriol 2004; $186(2)$ : $427-37$. [http://dx.doi.org/10.1128/JB.186.2.427-437.2004] [PMID: 14702312]

[76] Liebert CA, Hall RM, Summers AO. Transposon Tn21, flagship of the floating genome. Microbiol Mol Biol Rev 1999; 63(3): 507-22. [PMID: 10477306]

[77] Wireman J, Liebert CA, Smith T, et al. Association of mercury resistance with antibiotic resistance in the gram-negative fecal bacteria of primates. Association of Mercury Resistance with Antibiotic Resistance in the Gram-Negative Fecal Bacteria of Primates 1997; 63(11)

[78] Pepi M, Gaggi C, Bernardini E, et al. Mercury-resistant bacterial strains Pseudomonas and Psychrobacter spp. isolated from sediments of Orbetello Lagoon (Italy) and their possible use in bioremediation processes. Int Biodeterior Biodegradation 2011; 65(1): 85-91. [http://dx.doi.org/10.1016/j.ibiod.2010.09.006]

[79] Figueiredo NLL, Canário J, Duarte A, Serralheiro ML, Carvalho C. Isolation and characterization of mercury-resistant bacteria from sediments of Tagus Estuary (Portugal): Implications for environmental and human health risk assessment. J Toxicol Environ Health A 2014; 77(1-3): 155-68.

[http://dx.doi.org/10.1080/15287394.2014.867204] [PMID: 24555656]

[80] D SR. Prevalence of Mercury-Resistant and Antibiotic-Resistant Bacteria found in Dental Amalgam. 2014; 3(4): 1-4.

[81] Summers AO, Wireman J, Vimy MJ, et al. Mercury released from dental "silver" fillings provokes an increase in mercury- and antibioticresistant bacteria in oral and intestinal floras of primates. Antimicrob Agents Chemother 1993; 37(4): 825-34 [http://dx.doi.org/10.1128/AAC.37.4.825] [PMID: 8280208]

[82] Ball MM, Carrero P, Castro D, Yarzábal LA. Mercury resistance in bacterial strains isolated from tailing ponds in a gold mining area near El Callao (Bolívar State, Venezuela). Curr Microbiol 2007; 54(2): 149-54. [http://dx.doi.org/10.1007/s00284-006-0347-4] [PMID: 17200804]

[83] François F, Lombard C, Guigner JM, et al. Isolation and characterization of environmental bacteria capable of extracellular biosorption of mercury. Appl Environ Microbiol 2012; 78(4): 1097-106. [http://dx.doi.org/10.1128/AEM.06522-11] [PMID: 22156431]

[84] De J, Ramaiah N. Characterization of marine bacteria highly resistant to mercury exhibiting multiple resistances to toxic chemicals. Ecol Indic 2007; 7(3): 511-20. [http://dx.doi.org/10.1016/j.ecolind.2006.05.002]

[85] Bogdanova ES, Bass IA, Minakhin LS, et al. Horizontal spread of mer operons among gram-positive bacteria in natural environments. Microbiology 1998; 144(Pt 3): 609-20.

[http://dx.doi.org/10.1099/00221287-144-3-609] [PMID: 9534232]

[86] Dash HR, Sahu M, Mallick B, Das S. Functional efficiency of MerA protein among diverse mercury resistant bacteria for efficient use in bioremediation of inorganic mercury. Biochimie 2017; 142: 207-15. [http://dx.doi.org/10.1016/j.biochi.2017.09.016] [PMID: 28966143]

[87] Yu Z, Li J, Li Y, et al. A mer operon confers mercury reduction in a Staphylococcus epidermidis strain isolated from Lanzhou reach of the Yellow River. Int Biodeterior Biodegradation 1981; 90: 57-63. [http://dx.doi.org/10.1016/j.ibiod.2014.02.002]

[88] Naik MM, Dubey S. Lead-and mercury-resistant marine bacteria and their application in lead and mercury bioremediation Marine Pollution and Microbial Remediation. Springer 2017; pp. 29-40.

[89] Boyd ES, Barkay T. The mercury resistance operon: from an origin in a geothermal environment to an efficient detoxification machine. Front Microbiol 2012; 3: 349. [http://dx.doi.org/10.3389/fmicb.2012.00349] [PMID: 23087676]

[90] Sone Y, Nakamura R, Pan-hou H, Itoh T, Kiyono M. MerP in resistance to mercurials and the transport of mercurials in Escherichia coli. $2013 ; 36: 1835-41$.

[91] Jan AT, Azam M, Ali A, Haq QMR. Molecular characterization of mercury resistant bacteria inhabiting polluted water bodies of different geographical locations in India. Curr Microbiol 2012; 65(1): 14-21. [http://dx.doi.org/10.1007/s00284-012-0118-3] [PMID: 22488489]

[92] Wilson JR, Leang C, Morby AP, Hobman JL, Brown NL. MerF is a mercury transport protein: different structures but a common mechanism for mercuric ion transporters? FEBS Lett 2000; 472(1): 78-82. [http://dx.doi.org/10.1016/S0014-5793(00)01430-7] [PMID: 10781809] 
[93] Kiyono M, Oka Y, Sone Y, et al. Bacterial heavy metal transporter MerC increases mercury accumulation in Arabidopsis thaliana. Biochem Eng J 2013; 71: 19-24. [http://dx.doi.org/10.1016/j.bej.2012.11.007]

[94] Schué M, Dover LG, Besra GS, Parkhill J, Brown NL. Sequence and analysis of a plasmid-encoded mercury resistance operon from Mycobacterium marinum identifies MerH, a new mercuric ion transporter. J Bacteriol 2009; 191(1): 439-44. [http://dx.doi.org/10.1128/JB.01063-08] [PMID: 18931130]

[95] Schelert J, Rudrappa D, Johnson T, Blum P. Role of MerH in mercury resistance in the archaeon Sulfolobus solfataricus. Microbiology 2013; 159(Pt 6): 1198-208.

[http://dx.doi.org/10.1099/mic.0.065854-0] [PMID: 23619003]

[96] Kiyono M, Pan-Hou H. The merG gene product is involved in phenylmercury resistance in Pseudomonas strain K-62. J Bacteriol 1999; 181(3): 726-30. [PMID: 9922233]

[97] Osborn AM, Bruce KD, Strike P, Ritchie DA. Distribution, diversity and evolution of the bacterial mercury resistance (mer) operon. FEMS Microbiol Rev 1997; 19(4): 239-62. [http://dx.doi.org/10.1111/j.1574-6976.1997.tb00300.x] [PMID: 9167257]

[98] Das S, Dash HR, Chakraborty J. Genetic basis and importance of metal resistant genes in bacteria for bioremediation of contaminated environments with toxic metal pollutants. Appl Microbiol Biotechnol 2016; 100(7): 2967-84. [http://dx.doi.org/10.1007/s00253-016-7364-4] [PMID: 26860944]

[99] Schottel JL. The mercuric and organomercurial detoxifying enzymes from a plasmid-bearing strain of Escherichia coli. J Biol Chem 1978; 253(12): 4341-9. [PMID: 350872]

[100] Fermentation BK, Inage K, Chiba T, Metallic J, G S. Metallic in mercury-resistant pseudomonas has not and the electron described is containing group, and the enzyme for the decomposition mercuric chloride on bag, and subjected to a column (2.5 x $25 \mathrm{~cm})$ of DEAE. 1971 ; 36(12): 217-6.

[101] Essa AMM. The effect of a continuous mercury stress on mercury reducing community of some characterized bacterial strains. Afr J Microbiol Res 2012; 6(18): 4006-12.

[102] Pan-Hou H. [Application of mercury-resistant genes in bioremediation of mercurials in environments]. Yakugaku Zasshi 2010; 130(9): $1143-56$.

[http://dx.doi.org/10.1248/yakushi.130.1143] [PMID: 20823672]

[103] Parks JM, Guo H, Momany C, et al. Mechanism of Hg-C protonolysis in the organomercurial lyase MerB. J Am Chem Soc 2009; 131(37): 13278-85. [http://dx.doi.org/10.1021/ja9016123] [PMID: 19719173]

[104] Mathema VB, Krishna B, Thakuri C, Sillanpää M, Amatya R. Study of mercury (II) chloride tolerant bacterial isolates from Baghmati River with estimation of plasmid size and growth variation for the high mercury (II) resistant Enterobacter spp. Culture 2011; 72-.

[105] Sone Y, Mochizuki Y, Koizawa K, et al. Mercurial-resistance determinants in Pseudomonas strain K-62 plasmid pMR68. AMB Express $2013 ; 3(1): 41$. [http://dx.doi.org/10.1186/2191-0855-3-41] [PMID: 23890172]

[106] Guo H-B, Johs A, Parks JM, et al. Structure and conformational dynamics of the metalloregulator MerR upon binding of Hg(II). J Mol Biol 2010; 398(4): 555-68

[http://dx.doi.org/10.1016/j.jmb.2010.03.020] [PMID: 20303978]

[107] Park S-j, Wireman JOY, Summers A. Genetic Analysis of the Tn21 operator-promoter 1992; 174(7): $2160-71$.

[108] Chang C-C, Lin L-Y, Zou X-W, Huang C-C, Chan N-L. Structural basis of the mercury(II)-mediated conformational switching of the dualfunction transcriptional regulator MerR. Nucleic Acids Res 2015; 43(15): 7612-23. [http://dx.doi.org/10.1093/nar/gkv681] [PMID: 26150423]

[109] Haberstroh L, Silver S. 1984.

[110] Lee IW, Gambill BD, Summers AO. Translation of merD in Tn21. J Bacteriol 1989; 171(4): 2222-5. [http://dx.doi.org/10.1128/jb.171.4.2222-2225.1989] [PMID: 2539363]

[111] Wireman J, Liebert CA, Smith T, Summers AO. Association of mercury resistance with antibiotic resistance in the gram-negative fecal bacteria of primates. Appl Environ Microbiol 1997; 63(11): 4494-503. [PMID: 9361435]

[112] Zinder ND, Lederberg J. Genetic exchange in Salmonella. J Bacteriol 1952; 64(5): 679-99. [PMID: 12999698]

[113] Lederbergi J. Gene recombination in the bacterium Escherichia Coli. Nature 1947; 673-84.

[114] Frost LS, Leplae R, Summers AO, Toussaint A. Mobile genetic elements: the agents of open source evolution. Nat Rev Microbiol 2005; 3(9): 722-32. [http://dx.doi.org/10.1038/nrmicro1235] [PMID: 16138100] 
[115] Dash HR, Das S. Diversity, community structure, and bioremediation potential of mercury-resistant marine bacteria of estuarine and coastal environments of Odisha, India. Environ. Sci. Pollut Res. 2015.

[116] Rankin DJ, Rocha EPC, Brown SP. What traits are carried on mobile genetic elements, and why? Heredity (Edinb) 2011; 106(1): 1-10. [http://dx.doi.org/10.1038/hdy.2010.24] [PMID: 20332804]

[117] Dimitriu T, Misevic D, Lindner AB, Taddei F. Mobile genetic elements are involved in bacterial sociality. Mob Genet Elements 2015; 5(1): $7-11$.

[http://dx.doi.org/10.1080/2159256X.2015.1006110] [PMID: 26435881]

[118] Martinez JL. The role of natural environments in the evolution of resistance traits in pathogenic bacteria. Proc Biol Sci 2009; 276(1667): 2521-30. [http://dx.doi.org/10.1098/rspb.2009.0320] [PMID: 19364732]

[119] Martínez JL. Antibiotics and antibiotic resistance genes in natural environments. Science 2008; 321(5887): $365-7$. [http://dx.doi.org/10.1126/science.1159483] [PMID: 18635792]

[120] Bennett PM. Genome plasticity: insertion sequence elements, transposons and integrons, and DNA rearrangement. Methods Mol Biol 2004; 266: 71-113. [PMID: 15148416]

[121] Mindlin S, Kholodii G, Gorlenko Z, et al. Mercury resistance transposons of gram-negative environmental bacteria and their classification. Res Microbiol 2001; 152(9): 811-22. [http://dx.doi.org/10.1016/S0923-2508(01)01265-7] [PMID: 11763242]

[122] Bogdanova E, Minakhin L, Bass I, Volodin A, Hobman JL, Nikiforov V. Class II broad-spectrum mercury resistance transposons in Grampositive bacteria from natural environments. Res Microbiol 2001; 152(5): 503-14 [http://dx.doi.org/10.1016/S0923-2508(01)01224-4] [PMID: 11446519]

[123] Matsui K, Yoshinami S, Narita M, et al. Mercury resistance transposons in Bacilli strains from different geographical regions. FEMS Microbiol Lett 2016; 363(5): fnw013. [http://dx.doi.org/10.1093/femsle/fnw013] [PMID: 26802071]

[124] Liebert CA, Hall RM, Summers AO. Transposon Tn 21. Flagship of the Floating Genome 1999; 63(3): 507-22.

[125] Lal D, Lal R. Evolution of mercuric reductase (merA) gene: A case of horizontal gene transfer. Mikrobiologiia 2010; 79(4): 524-31. [PMID: 21058506]

[126] Hall JPJ, Harrison E, Lilley AK, Paterson S, Spiers AJ, Brockhurst MA. Environmentally co-occurring mercury resistance plasmids are genetically and phenotypically diverse and confer variable context-dependent fitness effects. Environ Microbiol 2015; 17(12): 5008-22. [http://dx.doi.org/10.1111/1462-2920.12901] [PMID: 25969927]

[127] Huang CC, Narita M, Yamagata T, Endo G. Identification of three merB genes and characterization of a broad-spectrum mercury resistance module encoded by a class II transposon of Bacillus megaterium strain MB1. Gene 1999; 239(2): 361-6. [http://dx.doi.org/10.1016/S0378-1119(99)00388-1] [PMID: 10548738]

[128] Laddaga RA, Chu L, Misra TK, Silver S. Nucleotide sequence and expression of the mercurial-resistance operon from Staphylococcus aureus plasmid pI258. Proc Natl Acad Sci USA 1987; 84(15): 5106-10. [http://dx.doi.org/10.1073/pnas.84.15.5106] [PMID: 3037534]

[129] Petrovski S, Blackmore DW, Jackson KL, Stanisich VA. Mercury(II)-resistance transposons Tn502 and Tn512, from Pseudomonas clinical strains, are structurally different members of the Tn5053 family. Plasmid 2011; 65(1): 58-64. [http://dx.doi.org/10.1016/j.plasmid.2010.08.003] [PMID: 20800080]

[130] Osborn AM, Bruce KD, Ritchie DA, Strike P. The mercury resistance operon of the IncJ plasmid pMERPH exhibits structural and regulatory divergence from other Gram-negative mer operons. Microbiology 1996; 142(Pt 2): 337-45. [http://dx.doi.org/10.1099/13500872-142-2-337] [PMID: 8932707]

[131] Narita M, Chiba K, Nishizawa H, et al. Diversity of mercury resistance determinants among Bacillus strains isolated from sediment of Minamata Bay. FEMS Microbiol Lett 2003; 223(1): 73-82. [http://dx.doi.org/10.1016/S0378-1097(03)00325-2] [PMID: 12799003]

[132] Wang Y, Moore M, Levinson HS, Silver S, Walsh C, Mahler I. Nucleotide sequence of a chromosomal mercury resistance determinant from a Bacillus sp. with broad-spectrum mercury resistance. J Bacteriol 1989; 171(1): 83-92. [http://dx.doi.org/10.1128/jb.171.1.83-92.1989] [PMID: 2536669]

[133] Griffin HG, Foster TJ, Silver S, Misra TK. Cloning and DNA sequence of the mercuric- and organomercurial-resistance determinants of plasmid pDU1358. Proc Natl Acad Sci USA 1987; 84(10): 3112-6. [http://dx.doi.org/10.1073/pnas.84.10.3112] [PMID: 3033633]

[134] Reniero D, Galli E, Barbieri P. Cloning and comparison of mercury- and organomercurial-resistance determinants from a Pseudomonas stutzeri plasmid. Gene 1995; 166(1): 77-82. [http://dx.doi.org/10.1016/0378-1119(95)00546-4] [PMID: 8529897]

[135] Kholodii GY, Mindlin SZ, Bass IA, Yurieva OV, Minakhina SV, Nikiforov VG. Four genes, two ends, and a res region are involved in transposition of Tn5053: A paradigm for a novel family of transposons carrying either a mer operon or an integron. Mol Microbiol 1995; 17(6): 1189-200. 
[http://dx.doi.org/10.1111/j.1365-2958.1995.mmi_17061189.x] [PMID: 8594337]

[136] Christopher M, Paul O, Hamadi B. Association of metal tolerance with multidrug resistance among Environmental Bacteria from wetlands of Lake Victoria Basin 2014.

[137] Zeyaullah M, Islam B, Ali a. Isolation, identification and PCR amplification of merA gene from highly mercury polluted Yamuna river. Afr J Biotechnol 2010; 9(24): 3510-4.

[138] Pal C, Bengtsson-Palme J, Kristiansson E, Larsson DGJ. Co-occurrence of resistance genes to antibiotics, biocides and metals reveals novel insights into their co-selection potential. BMC Genomics 2015; 16: 964. [http://dx.doi.org/10.1186/s12864-015-2153-5] [PMID: 26576951]

[139] Trajanovska S, Britz ML, Bhave M. Detection of heavy metal ion resistance genes in gram-positive and gram-negative bacteria isolated from a lead-contaminated site. Biodegradation 1997; 8(2): 113-24. [http://dx.doi.org/10.1023/A:1008212614677] [PMID: 9342884]

[140] Diels L, Mergeay M. DNA probe-mediated detection of resistant bacteria from soils highly polluted by heavy metals. Appl Environ Microbiol 1990; 56(5): 1485-91. [PMID: 16348196]

[141] Bruce KD, Hiorns WD, Hobman JL, Osborn AM, Strike P, Ritchie DA. Amplification of DNA from native populations of soil bacteria by using the polymerase chain reaction. Appl Environ Microbiol 1992; 58(10): 3413-6. [PMID: 1444376]

[142] Georgios M, Egki T. Phenotypic and Molecular Methods for the Detection of Antibiotic Resistance Mechanisms in Gram Negative Nosocomial Pathogens. Intech 2014.

[http://dx.doi.org/10.5772/57582]

[143] Barkay T, Fouts DL, Olson BH. Preparation of a DNA gene probe for detection of mercury resistance genes in gram-negative bacterial communities. Appl Environ Microbiol 1985; 49(3): 686-92. [PMID: 3994373]

[144] Baldi F, Gallo M, Marchetto D, Faleri C, Maida I, Fani R. Manila clams from Hg polluted sediments of Marano and Grado lagoons (Italy) harbor detoxifying $\mathrm{Hg}$ resistant bacteria in soft tissues. Environ Res 2013; 125: 188-96. [http://dx.doi.org/10.1016/j.envres.2012.11.008] [PMID: 23398778]

[145] Unc A, Zurek L, Peterson G, Narayanan S, Springthorpe SV, Sattar SA. Microarray assessment of virulence, antibiotic, and heavy metal resistance in an agricultural watershed creek. J Environ Qual 2012; 41(2): 534-43. [http://dx.doi.org/10.2134/jeq2011.0172] [PMID: 22370416]

[146] Osborn AM, Bruce KD, Strike P, Ritchie DA. Polymerase Chain Reaction-Restriction Fragment Length Polymorphism Analysis Shows Divergence among mer Determinants from Gram-Negative Soil Bacteria Indistinguishable by DNA-DNA Hybridization 1993.

[147] N. Mirzazei FK, Kargar M. Isolation and identification of mercury resistant bacteria from Kor river, Iran. 2008; pp. 935-9.

[148] Taylor P, Figueiredo NLL, Areias A, Mendes R, Canário J, Duarte A. Mercury-Resistant Bacteria From Salt Marsh of Tagus Estuary: The Influence of Plants Presence and Mercury Contamination Levels. J Toxicol Environ Health 2014; •••: 37-41.

[149] Cao D-j, Tian Z-f. Isolation and identification of a mercury resistant strain. Environ Prot Eng 2012; 38(4)

[150] Summers AO, Lewis E. Volatilization of mercuric chloride by mercury-resistant plasmid-bearing strains of Escherichia coli, Staphylococcus aureus, and Pseudomonas aeruginosa. J Bacteriol 1973; 113(2): 1070-2. [PMID: 4632313]

[151] Nakamura K, Nakahara H. Simplified X-ray film method for detection of bacterial volatilization of mercury chloride by Escherichia coli. Appl Environ Microbiol 1988; 54(11): 2871-3.

[PMID: 3063210]

[152] Lian P, Guo H-b, Riccardi D, Dong A, Parks JM, Xu Q. X-ray Structure of a Hg ${ }^{2+}$ Complex of Mercuric Reductase (MerA) and Quantum Mechanical/Molecular Mechanical Study of $\mathrm{Hg}^{2+}$ Transfer between the C-Terminal and Buried Catalytic Site Cysteine Pairs. 2014.

[153] Freedman Z, Zhu C, Barkay T. Mercury resistance and mercuric reductase activities and expression among chemotrophic thermophilic Aquificae. Appl Environ Microbiol 2012; 78(18): 6568-75. [http://dx.doi.org/10.1128/AEM.01060-12] [PMID: 22773655]

[154] Sandström A, Lindskog S. Activation of mercuric reductase by the substrate NADPH. Eur J Biochem 1987; 164(1): 243-9. [http://dx.doi.org/10.1111/j.1432-1033.1987.tb11017.x] [PMID: 3104042]

[155] Ogunseitan OA. Protein method for investigating mercuric reductase gene expression in aquatic environments. Appl Environ Microbiol 1998; 64(2): 695-702. [PMID: 9464410]

[156] Umrania VV. Bioremediation of toxic heavy metals using acidothermophilic autotrophes. Bioresour Technol 2006; $97(10)$ : $1237-42$. [http://dx.doi.org/10.1016/j.biortech.2005.04.048] [PMID: 16324838]

[157] Bizily SP, Rugh CL, Summers AO, Meagher RB. Phytoremediation of methylmercury pollution: merB expression in Arabidopsis thaliana confers resistance to organomercurials. Proc Natl Acad Sci USA 1999; 96(12): 6808-13. [http://dx.doi.org/10.1073/pnas.96.12.6808] [PMID: 10359794] 
[158] Bizily SP, Rugh CL, Meagher RB. Phytodetoxification of hazardous organomercurials by genetically engineered plants. Nat Biotechnol 2000; 18(2): 213-7.

[http://dx.doi.org/10.1038/72678] [PMID: 10657131]

[159] Hsieh J-L, Chen C-Y, Chiu M-H, et al. Expressing a bacterial mercuric ion binding protein in plant for phytoremediation of heavy metals. J Hazard Mater 2009; 161(2-3): 920-5. [http://dx.doi.org/10.1016/j.jhazmat.2008.04.079] [PMID: 18538925]

[160] Sasaki Y, Hayakawa T, Inoue C, Miyazaki A, Silver S, Kusano T. Generation of mercury-hyperaccumulating plants through transgenic expression of the bacterial mercury membrane transport protein MerC. Transgenic Res 2006; 15(5): 615-25. [http://dx.doi.org/10.1007/s11248-006-9008-4] [PMID: 16830224]

[161] Schelert J, Drozda M, Dixit V, Dillman A, Blum P. Regulation of mercury resistance in the crenarchaeote Sulfolobus solfataricus. J Bacteriol 2006; 188(20): 7141-50. [http://dx.doi.org/10.1128/JB.00558-06] [PMID: 17015653]

\section{(C) 2018 Naguib et al.}

This is an open access article distributed under the terms of the Creative Commons Attribution 4.0 International Public License (CC-BY 4.0), a copy of which is available at: (https://creativecommons.org/licenses/by/4.0/legalcode). This license permits unrestricted use, distribution, and reproduction in any medium, provided the original author and source are credited. 